\title{
Development of Advanced Conformal Ablative TPS Fabricated from Rayon- and PAN-Based Carbon Felts
}

\author{
Matthew Gasch, Mairead Stackpoole, Susan White \\ NASA Ames Research Center, Moffett Field, CA, 94035 \\ Tane Boghozian \\ ERC at NASA Ames Research Center, Moffett Field, CA, 94035
}

\begin{abstract}
The conformal ablative TPS first developed under NASA's Hypersonics Project in the early 2000's demonstrated very low through the thickness conductivity compared to state-ofthe-art PICA. However, in initial arcjet testing of Conformal-1, surface recession rates were 2x higher than PICA. Because commercial carbon felts are currently available as very thin substrates, this was a concern if conformal TPS were to be considered for a mission that required thicker material. Discussed in this paper are the results of the development of an Advanced Conformal TPS derived from thicker, higher density carbon felt. Two substrate systems were evaluated, the first material was a needled rayon-based carbon felt and the other a needled PAN-based carbon felt. Both substrates were impregnated with phenolic resin following the PICA/CPICA process to add a low density phenolic matrix to the system prior to aerothermal screening at the LaRC HyMETS facility and larger scale testing in the NASA ARC Interaction Heating Facility (IHF) at heating fluxes ranging from 250-1700 $\mathrm{W} / \mathrm{cm}^{2}$.
\end{abstract}

Nomenclature
PICA

\begin{abstract}
A conformable Thermal Protection System (TPS) over a rigid aeroshell has the potential to solve a number of Achallenges faced by traditional rigid TPS materials such as tiled Phenolic Impregnated Carbon Ablator (PICA). ${ }^{1-2}$ The compliant (high strain to failure) nature of conformable ablative materials can be attributed to the loose network of carbon fibers within the felt substrate. Although rigid after infiltration with phenolic resin following a modified PICA process, the lack of rigid connectivity within the felt substrate allows the system to be able to accommodate large non-linear strain without catastrophic failure. This in turn has the potential to allow larger segments to be used without strain isolation which would reduce part count on a large vehicle. The high strain to failure of conformal ablators should also allow for integration over wide range of carrier structures, potentially allowing changes to the substructure later in the design phase, without detriment to the TPS design.

Lack of rigid connectivity in the carbon felt substrate also serves to limit thermal transport through the thickness (TTT). This was first observed in the Conformal-1 system which was first developed under the Hypersonics Project in the early 2000's. ${ }^{\alpha}$ Initial arcjet testing of in-depth instrumented samples at $\sim 1000 \mathrm{~W} / \mathrm{cm}^{2}$ demonstrated conformal TPS has excellent heat load capability in terms of lower back-face temperature compared to SoA PICA. ${ }^{3}$ However, when compared to the rigid PICA system, surface recession rates of the felt-based Conformal-1 were approximately $2 \mathrm{x}$ greater than that of PICA. Ablation is of course a welcome process because it gets rid of hot material. And, more often than not, higher ablation leads to lower sized TPS mass. The concern however is that the commercially available felt used in Conformal-1 was only available in a thickness of up to 1 -inch, and at one density. And at $2 \mathrm{x}$
\end{abstract}

${ }^{a}$ Fiber-Reinforced Composite Materials”, NASA Case No. ARC-16692-1 (U.S. Patent Appl. No. 13/357,248) 
the recession of PICA, the Conformal-1 system would need to be much thicker to be a viable candidate for an actual mission.

Upon inspection, the higher ablation of Conformal- 1 can be attributed to its lower TPS density $\left(0.21 \mathrm{~g} / \mathrm{cm}^{3}\right) \mathrm{vs}$. that of PICA $\left(0.28 \mathrm{~g} / \mathrm{cm}^{3}\right)$ which is the result of the two different starting substrate densities - Morgan VDG carbon felt at $0.09 \mathrm{~g} / \mathrm{cm}^{3}$ vs. FiberForm ${ }^{\mathrm{TM}}$ which has a density of $0.17 \mathrm{~g} / \mathrm{cm}^{3}$. Thus the desire for conformal TPS to accommodate higher levels of mechanical shear likely requires an increase in material density. However, optimum TPS performance is clearly a trade-off between the density of a material and the thermal response the TPS. An increase in TPS density can be accomplished either by increasing the amount of resin (increased resin loading) or by increasing the felt density. In the low density carbon felt based ablative thermal protection materials of interest here, the loose network of carbon fibers acts as a framework for the pyrolyzing resin to adhere. The loose network minimizes thermal contact between fibers. An increased resin loading can then be used to increase material density while preserving the loose contact of the fibers in the felt. Unfortunately there is a limit to the amount of resin that a low-density felt can accommodate because the lower the felt density, the less through-the-thickness interlocking there is between fibers. As shown in Figure 1, the addition of extra resin to increase TPS density can cause a felt substrate to delaminate if the fibers in the substrate are not sufficiently interlocked. A higher density felt would resolve this problem allowing the use of lower density resin, while meeting the need for strength in the fiber reinforcement component of the composite material.

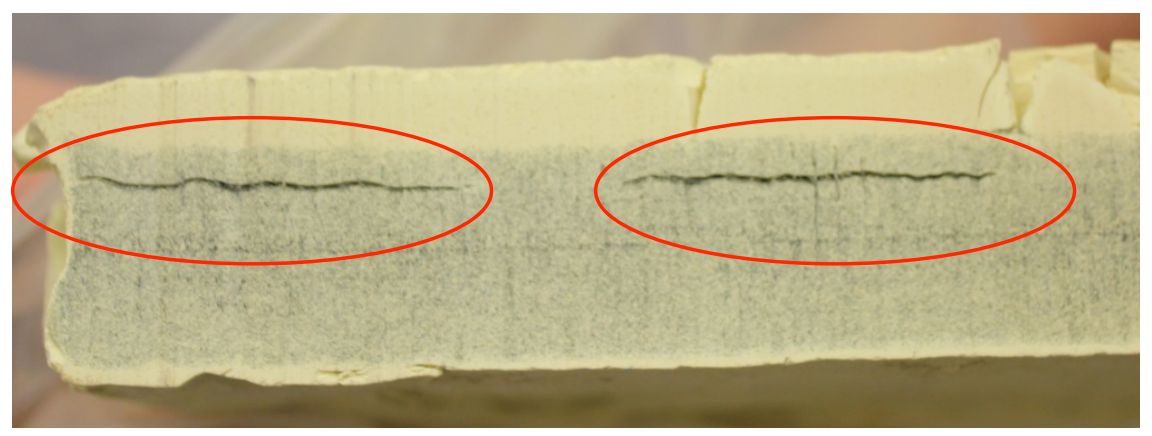

Figure 1. Example of felt delamination as a result of shrinkage stresses from phenolic cure process.

To better understand the effect of increased substrate density on recession within a carbon felt based TPS, the degree of carbon fiber interlocking was studied. The investigation was limited to commercially available substrates and commercially available needling capabilities. The two carbon felt systems that were investigated during this effort were polyacrylonitrile (PAN) -based and a rayon-based felts. After infusion with phenolic resin to add a low density phenolic matrix to the system, all materials were then screened under simulated aerothermal re-entry conditions $\left(400 \mathrm{~W} / \mathrm{cm}^{2}\right)$ at the HyMETS facility at NASA LaRC and larger scale testing in the NASA ARC Interaction Heating Facility (IHF) at heating fluxes ranging from $250-1700 \mathrm{~W} / \mathrm{cm}^{2}$.

\section{Investigation of Advanced Conformal Carbon Felt Substrates}

Carbon felt substrates made from either Rayon or PAN were used as the high-temperature reinforcing component of the materials of interest in this work. Both substrates investigated covered a range of densities, and production methods. PAN based carbon felts have more suppliers, sustainable sources of raw material and are more readily available over a range of properties. PAN-based carbon felts also have characteristically high strength and tensile modulus. On the other hand, rayon-based carbon fiber felts are of great interest for low thermal conductivity. The most efficient composition for a new TPS materials however, requires the optimization of strength versus thermal properties.

The current SoA Conformal-PICA (CPICA) system utilizes commercially available 1-inch thick Morgan VDG carbon felt made from rayon (Morgan Advanced Materials, Fostoria, Ohio). When carbonized this felt has a substrate density that is roughly $0.09 \mathrm{~g} / \mathrm{cm}^{3}$. Under this effort, the procurement and/or development of felts that are more structurally integrated (higher density with increased z-direction fiber reinforcement) was sought. The felts that were investigated were produced with carbonized density ranging between $0.14-0.45 \mathrm{~g} / \mathrm{cm}^{3}$. Felt thicknesses greater than 1-inch were also sought as it is recognized that thicknesses greater than 1-inch will likely be required if the material is to be used as a TPS for re-entry probes. A summary of the substrates investigated is given in Table 1. 
Table 1. Current Conformal 1 (CPICA) carbon felt substrate and alternate carbon felts that were investigated during this study for use in developing an Advanced Conformal TPS.

\section{Conformal-1 and CPICA Carbon Felt Substrate}

\begin{tabular}{|c|c|c|c|}
\hline Morgan VDG & Density & Thickness & Description \\
\cline { 2 - 4 } (Rayon Based) & $0.09 \mathrm{~g} / \mathrm{cm}^{3}$ & 1 -inch & CPICA Baseline \\
\hline
\end{tabular}

\section{Advanced Conformal Carbon Felt Substrate Options}

\begin{tabular}{|c|c|c|c|}
\hline \multirow{4}{*}{ Pan-Based } & Density & Thickness & Description \\
\cline { 2 - 4 } & $0.14 \mathrm{~g} / \mathrm{cm}^{3}$ & 1-inch & PAN 1 - P1 \\
\cline { 2 - 4 } & $0.17 \mathrm{~g} / \mathrm{cm}^{3}$ & 2-inch & PAN 2 - P2 \\
\cline { 2 - 4 } & $0.17 \mathrm{~g} / \mathrm{cm}^{3}$ & 3-inch & PAN 3 - P3 \\
\cline { 2 - 4 } & $0.45 \mathrm{~g} / \mathrm{cm}^{3}$ & 1-inch & PAN 4 - P4 \\
\hline \multirow{4}{*}{ Rayon-Based } & Density & Thickness & Description \\
\cline { 2 - 4 } & $0.14 \mathrm{~g} / \mathrm{cm}^{3}$ & 3-inch & Rayon 1 - R1 \\
\cline { 2 - 4 } & $0.16 \mathrm{~g} / \mathrm{cm}^{3}$ & 1/2-inch & Rayon 2 - R2 \\
\cline { 2 - 4 } & $0.19 \mathrm{~g} / \mathrm{cm}^{3}$ & 3/8-inch & Rayon 3 - R3 \\
\cline { 2 - 4 } & $0.20 \mathrm{~g} / \mathrm{cm}^{3}$ & $1 / 2$-inch & Rayon 4 - R4 \\
\hline
\end{tabular}

\section{A. PAN-Based Carbon Felt Investigation}

PAN-based carbon fiber composites and felts have been continuously developed for a range of uses over several decades, and consequently are commercially available in a wide range of strength, density and thickness. Used in large volume, PAN-based carbon fibers and felts offer a commercially sustainable choice of substrate with interesting potential to exploit for NASA applications. The intrinsic thermal conductivity of PAN fibers is higher than that of other fibers however, the commercial availability PAN and ability to tailor thermal and mechanical properties of PAN fiber composites may offer useful tradeoffs. Photos of some of the PAN-based carbon felts produced under this effort are shown in Figure 2. All PAN-based felt products used in this work were produced by American Structural Needling Company ASNC (Tallassee, AL).
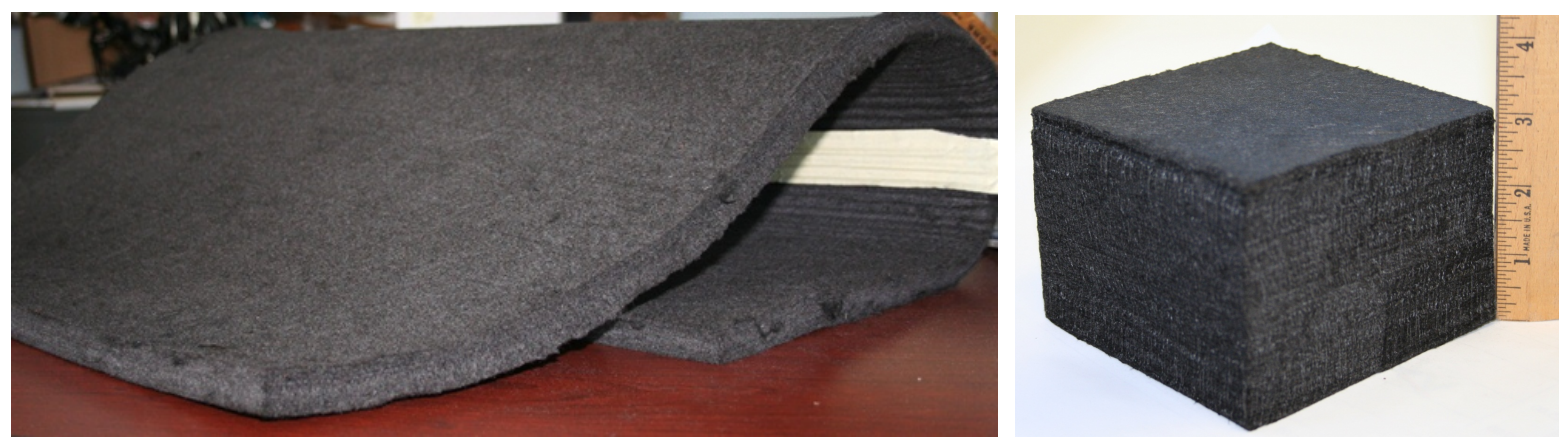

Figure 2. PAN-based felt materials showing flexibility of this material system and manufacturability up to 3 -inch thickness. 


\section{B. Rayon-Based Carbon Felt Investigation}

Historically NASA has used rayon-based carbon fiber materials for heatshield applications because of their favorable thermal properties, namely low conductivity compared to PAN fibers. Rayon fibers are also produced on very large scale commercially for textile as well as aerospace applications. However, the process of making rayon requires high temperatures and environmentally un-friendly chemicals. Thus there is currently no domestic supply for rayon as strict US environmental policies have pushed all rayon factories off-shore. In addition to being a foreign import, sustainability of manufacturing facilities has been very challenging. For example early TPS materials used Avtex rayon. When that was no longer available the community was forced to switch to rayon from the North American Rayon Corporation (NARC) until that too was unavailable. These disruptions in supply have the potential to result in costly requalification efforts. Nevertheless, the favorably low thermal conductivity of rayon-based TPS keeps it a contender for aerospace heatshield applications; thus the inclusion of rayon in these studies.

Recent evaluations of cellulose fibers (Lyocell/Tencel ${ }^{\circledR}$ ) as precursors to rayon derived fibers are receiving some attention. Cellulose fibers provide high purity and excellent thermal performance when compared to rayon derived fibers and may be a viable alternative. While felts from a cellulose precursor were not evaluated in this study they will be considered in future work.

Rayon felts were procured from American Felt and Filter Company (AFFCO) of Newburg, NY. Substrate R1 was produced under a prior NASA contract (NNA12AB29P) for the Conformal Ablators -TPS Project (CA-TPS) with AFFCO whereby the vendor developed a specialized process to fabricate a 4-inch thick rayon felt with a starting density roughly double that of the material that is provided to Morgan for processing into their commercial VDG felt. Panels that were fabricated under the AFFCO thick felt effort were $\sim 40$-inch wide by $\sim 80$-inch long.

For samples R2-R4, standard production 1.5-inch thick rayon felts were procured from AFFCO and then postprocessed by TEAM Inc. (Woonsocket, RI) in a series of trials in which the NASA supplied materials were processed through TEAM's needling line to determine maximum density (fiber volume) that could be achieved without significant degradation / damage to the rayon felt. The 3 material panels that were fabricated by TEAM were a lab-scale effort only and were much smaller, each only $\sim 2 \mathrm{ft}$ long $\mathrm{x} 1 \mathrm{ft}$ wide. Foreign object debris (FOD) presence in the form of broken needles was observed in all three of the TEAM processed samples to some degree. In sample R2 it was noticed that only needle stems were hitting the fabric in some areas which could skew properties and damage the rayon felt resulting in poor mechanical performance. Since this was a trial process, further optimization could reduce needle breakage and the presence of FOD. A summary of the properties of the rayon substrates after various processes to increase density is provided in Table 2. Photos of the Rayon felts (precarbonization) are shown in Figure 3.

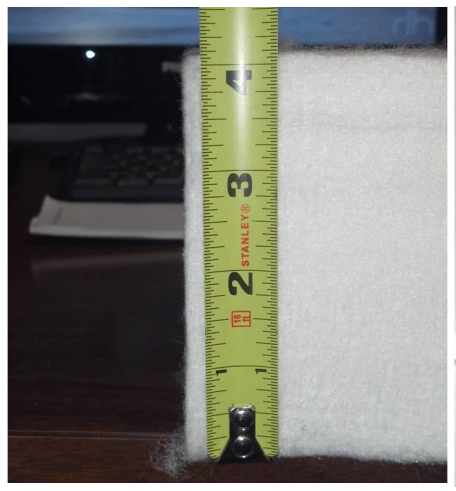

(a)

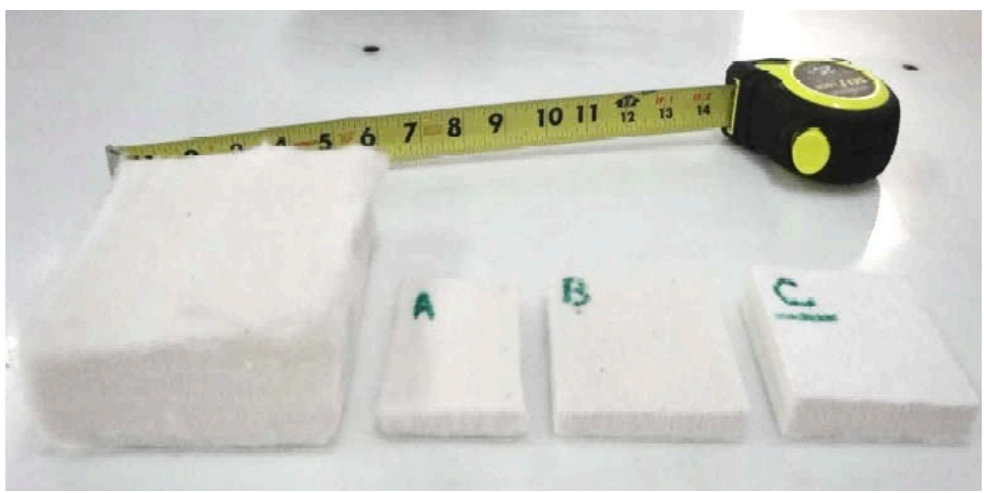

(b)

Figure 3. Rayon-based felt materials showing (a) sample R1 white-goods manufacturability $>4$-inch (3-inch post carbonization thickness) and (b) samples R2 to R4 thickness after needling a standard production 1.5 -inch thick rayon felt. 
Table 2. Properties of Rayon Felts R2-R4 after needling investigation at TEAM.

\begin{tabular}{|c|c|c|c|c|}
\hline $\begin{array}{c}\text { Rayon } \\
\text { Felt }\end{array}$ & $\begin{array}{c}\text { Starting } \\
\text { Thickness } \\
\text { (in) }\end{array}$ & $\begin{array}{c}\text { Final } \\
\text { Thickness } \\
\text { (in) }\end{array}$ & $\begin{array}{c}\text { Estimated } \\
\text { Fiber Volume } \\
\text { Fraction (\%) }\end{array}$ & $\begin{array}{c}\text { Estimated Felt } \\
\text { Density (g/cm } \mathbf{~} \text { ) }\end{array}$ \\
\hline R2 & 1.5 & 0.67 & 23 & 0.34 \\
\hline R3 & 1.5 & 0.46 & 20 & 0.30 \\
\hline R4 & 1.5 & 0.46 & 23 & 0.35 \\
\hline
\end{tabular}

All 4 rayon felts were then carbonized in an inert environment to $1900^{\circ} \mathrm{C}$ by Fiber Materials Inc. (FMI) of Biddeford, ME. Substantial felt shrinkage is observed during the carbonization process. Photos of the Rayon felts (post-carbonization) are shown in Figure 3. On examination of the carbonized felts it was noted that sample R2 had a lower density than expected post carbonization. This is attributed to the substantial needle breakage that occurred during the processes used to increase the fiber volume fraction of that felt. Substantial damage to the felt occurred weakening the thru-the-thickness fiber connections that were binding the felt. This indicates that process optimization is needed to produce a rayon felt of the desired fiber volume fraction without causing substantial degradation to the felt in the process.

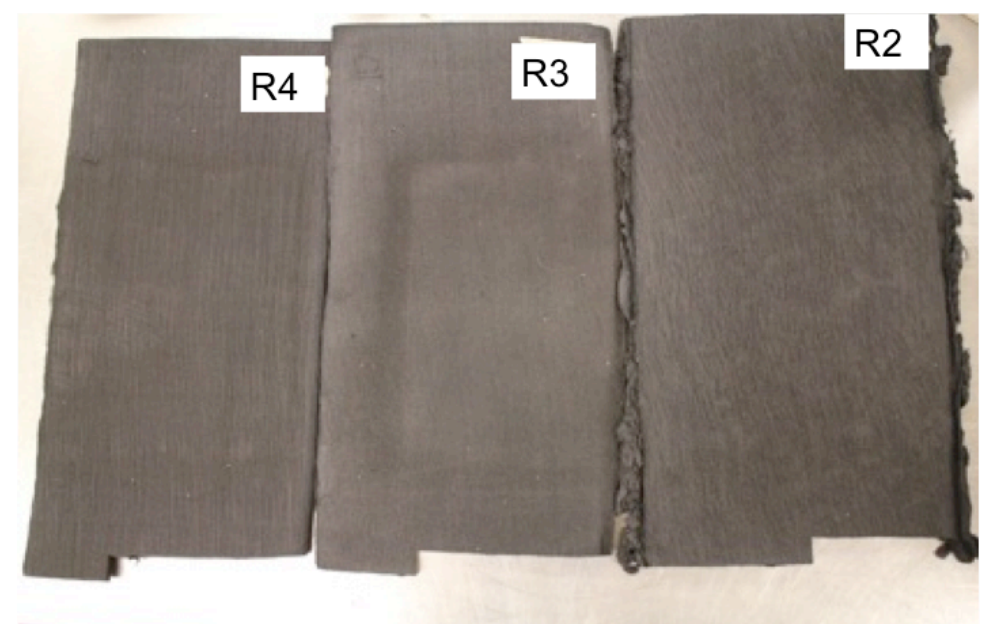

Figure 4. Rayon-based felt materials post carbonization.

\section{Resin Infusion of PAN and Rayon Carbon Felts}

Felt substrates were infused with phenolic resin by two different methods. The first method was the standard PICA process. The second method, which yields conformal phenolic impregnated carbon ablator (CPICA), uses a proprietary modified polymer recipe and a higher phenolic resin content which is > PICA. These two infusion methods will be referred to as "PICA" and "CPICA" respectively. 


\section{HyMETS Aerothermal Testing}

\section{A. Test Objective and Specimen Description}

PAN and Rayon-based carbon felt conformal ablator concepts were subjected to HyMETS testing at the conditions listed in Table 3 to support subsequent down-selection of the most promising felt candidates for further development. Current facility capabilities limit the maximum heating on the 1.3-inch diameter samples to 400 $\mathrm{W} / \mathrm{cm}^{2}$ at a stagnation pressure of $4 \mathrm{kPa}$. All specimens were infiltrated with phenolic as described previously.

Table 3. HyMETS Test Conditions

\begin{tabular}{|c|c|c|c|}
\hline $\begin{array}{c}\text { Cold Wall } \\
\text { Heat Flux } \\
\left(\mathbf{W} / \mathbf{c m}^{2}\right)\end{array}$ & $\begin{array}{c}\text { Stagnation } \\
\text { Pressure } \\
\text { (atm) }\end{array}$ & $\begin{array}{c}\text { Bulk } \\
\text { Enthalpy } \\
\text { (kJ/g) }\end{array}$ & $\begin{array}{c}\text { Test } \\
\text { Time } \\
\text { (sec) }\end{array}$ \\
\hline 400 & 0.05 & 40.9 & 30 \\
\hline
\end{tabular}

Ablator test specimens were 1-inch diameter with a thickness of $\sim 0.9$ inches. Each ablator test specimen was bonded into a 1.3-inch outer diameter LI-2200 tile collar to minimize side heating effect, as shown Figure 5. A graphite sting adapter was bonded to the back of each assembly for interface to the HYMETS sting arm.

Table 4. HyMETS Test Matrix.

\begin{tabular}{|c|c|c|c|}
\hline Sample ID & Substrate Density & Infusion & $\begin{array}{c}\text { TPS } \\
\text { Density }\end{array}$ \\
\hline HyMETS 1 & 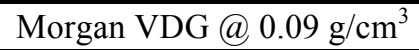 & CPICA & $0.29 \mathrm{~g} / \mathrm{cm}^{3}$ \\
\hline HyMETS 2 & 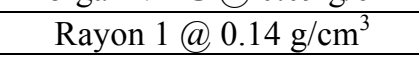 & CPICA & $0.29 \mathrm{~g} / \mathrm{cm}^{3}$ \\
\hline HyMETS 3 & Rayon3@0.19 g/ $/ \mathrm{cm}^{3}$ & CPICA & $0.24 \mathrm{~g} / \mathrm{cm}^{3}$ \\
\hline HyMETS 4 & Rayon $4 @ 0.20 \mathrm{~g} / \mathrm{cm}^{3}$ & CPICA & $0.29 \mathrm{~g} / \mathrm{cm}^{3}$ \\
\hline HyMETS 5 & PAN1@0.14 g/cm ${ }^{3}$ & CPICA & $0.29 \mathrm{~g} / \mathrm{cm}^{3}$ \\
\hline HyMETS 6 & PAN $2 @ 0.17 \mathrm{~g} / \mathrm{cm}^{3}$ & CPICA & $0.31 \mathrm{~g} / \mathrm{cm}^{3}$ \\
\hline HyMETS 7 & 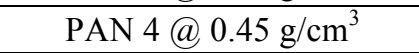 & CPICA & $0.31 \mathrm{~g} / \mathrm{cm}^{3}$ \\
\hline
\end{tabular}

The instrumentation for these tests consisted of a two-color pyrometer to measure surface temperature, a Gardon gauge to measure cold wall heat flux, and a Pitot tube to measure stagnation pressure. Bulk enthalpy calculation was made using a thermopile to measure the differential temperature across the inlet and outlet of the cooling water manifolds for the arc plasma generator and flow meters to measure the mass flow rates for both the cooling water and the arc column test gas.
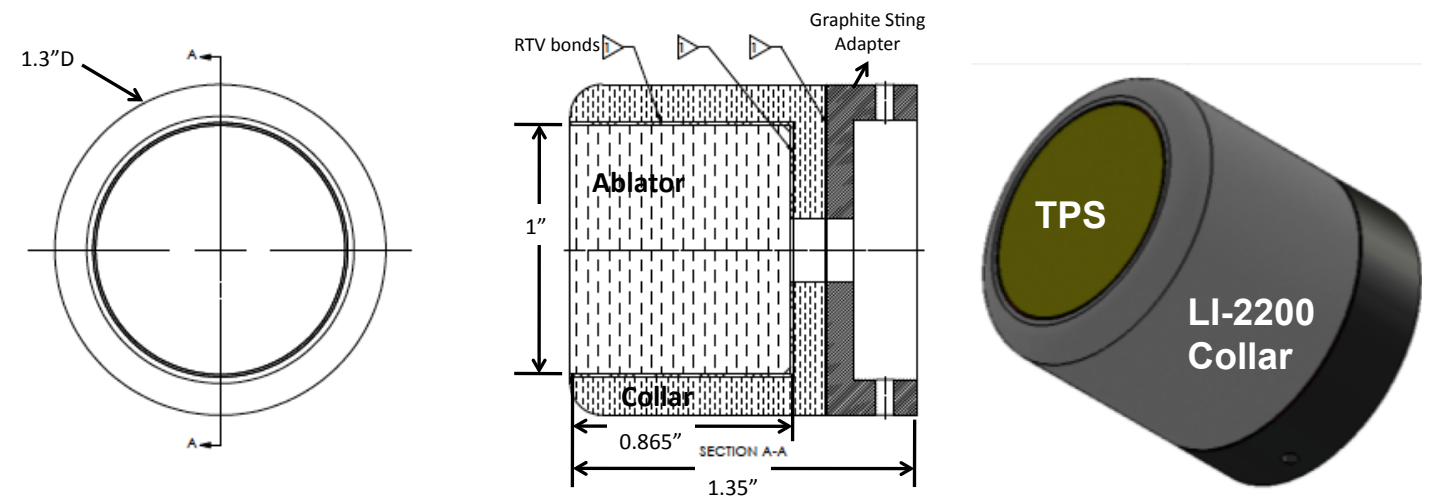

Figure 5. HyMETS test specimen. 


\section{B. HyMETS Results}

The height of pre-test and post-test samples were measured using digital calipers. Recession was then calculated from the displacement between the pre- and post-test shapes with an estimated uncertainty of $0.25 \mathrm{~mm}$. Normalized sample density, mass loss and recession are summarized in Figure 6. After 30 seconds in the flow, the Morgan and AFFCO rayon models experienced very similar mass loss and recession. The TEAM processed rayon samples both had the highest mass loss but had varied recession. All of the PAN models showed less mass loss and recession than any of the rayon materials.

Based on the results from HyMETS screening, in combination with the processing histories discussed in Section I, Morgan and AFFCO rayon substrates were selected for further study. The 0.14 and the $0.17 \mathrm{~g} / \mathrm{cm} 3 \mathrm{PAN}$ substrates were also selected for further study. The rayon felts processed by TEAM were not carried forward because the substrates were not able to be processed to the minimum 1-inch thickness desired by the program. Although the 0.45 $\mathrm{g} / \mathrm{cm} 3$ PAN substrate had the lowest recession it was also eliminated from further study at this time.

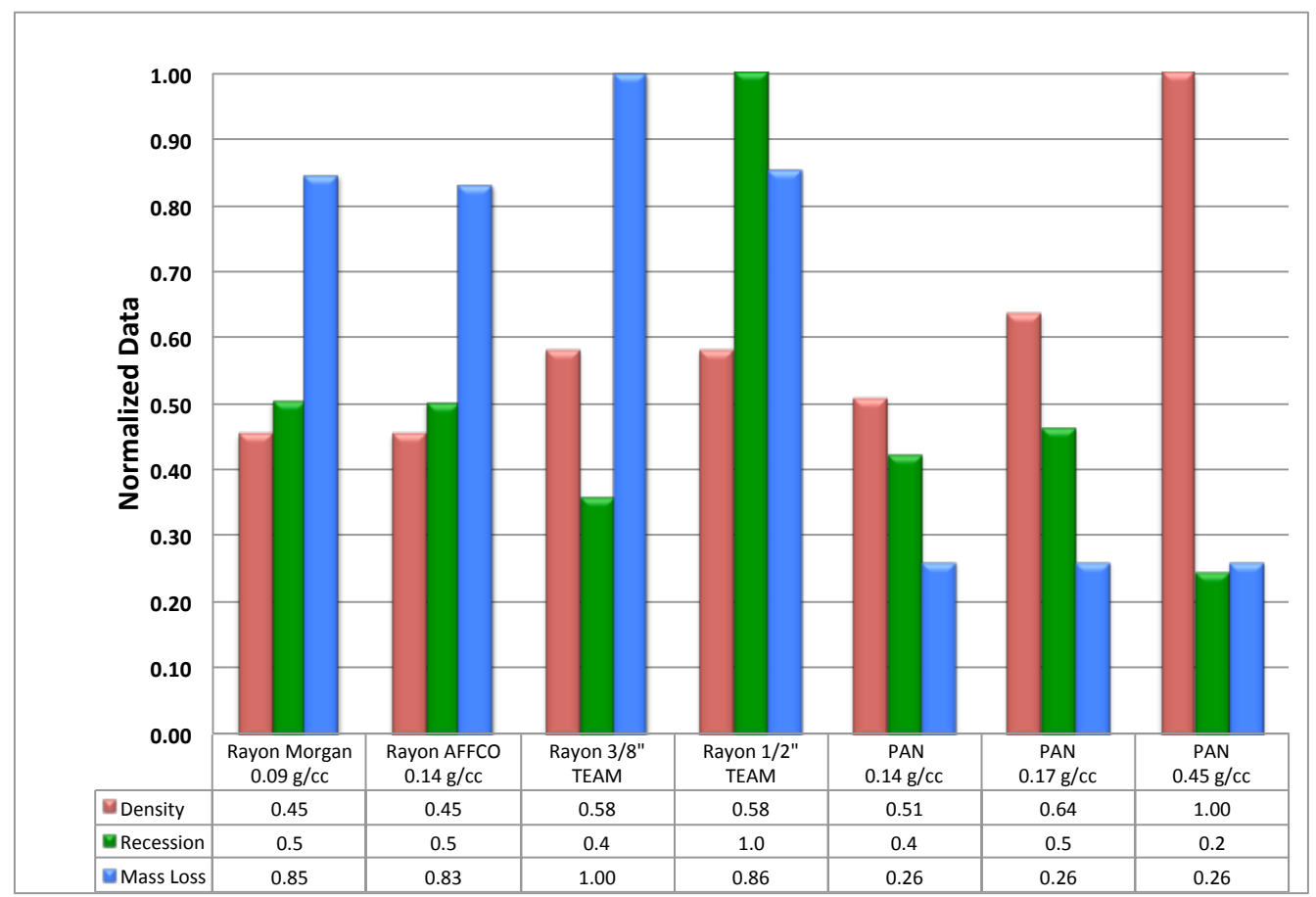

Figure 6. Normalized HyMETS data - sample density, recession and mass loss.

\section{IHF High Heat Flux Testing}

PAN and rayon-based carbon felt configurations that were downselected from the HyMETS testing were next tested in NASA's IHF facility in two configurations: ${ }^{4}$ 1) a 2-inch diameter flat-face stagnation and 2) a sphere-cone (Small Probe Reentry Investigation of TPS Engineering or "SPRITE") configuration that allowed a combination of heat flux, pressure, and shear to be attained on 4 TPS test samples siumltaneously. ${ }^{5}$ The objectives of these two test campaigns built on previous successes in developing conformal ablators while also beginning to address material repeatability and in-depth temperature response. ${ }^{6}$ As mentioned previously, the materials under consideration for subsequent test series consisted of 2 rayon-based carbon felts: 1) the baseline Morgan felt $\left(0.09 \mathrm{~g} / \mathrm{cm}^{3}\right) \mathrm{and} \mathrm{2)}$ the 3inch thick needled AFFCO Rayon $\left(0.14 \mathrm{~g} / \mathrm{cm}^{3}\right)$ as well as two PAN-based carbon felts with densities of 0.14 and $0.17 \mathrm{~g} / \mathrm{cm}^{3}$ respectively. All materials were infiltrated with phenolic following either a PICA or a CPICA process as described previously. 


\section{A. IHF High Heat Flux Test Description}

The IHF High Heat test series consisted of 1 day in the IHF facility with the 6-inch diameter nozzle. A description of the models tested is listed in Table 5 and schematic of the model assembly is shown in Figure 7. All test articles were 2-inch diameter flat-face. The primary objective of this test series was to gather recession data on several CPICA formulations in a high heat flux environment $\sim 1750 \mathrm{~W} / \mathrm{cm}^{2}$. Models were not instrumented. The tests were conducted according to the facility conditions specified in Table 5. A 4-inch IsoQ copper slug calorimeter was used to characterize the arc jet flow. The heating environment experienced on the 2 -inch flat face models was determined using CFD as shown in Figure 8. Pre-test images of a typical test article are shown in Figure 9.

Table 5. IHF High Heat Flux Test Matrix.

\begin{tabular}{|c|c|c|c|}
\hline Sample ID & Substrate & Infusion & $\begin{array}{c}\text { TPS } \\
\text { Density }\end{array}$ \\
\hline HEDL 1* & Morgan VDG@0.09g/ $\mathrm{cm}^{3}$ & CPICA & $0.29 \mathrm{~g} / \mathrm{cm}^{3}$ \\
\hline HEDL 2 & Rayon1@0.14 g/ $\mathrm{cm}^{3}$ & CPICA & $0.28 \mathrm{~g} / \mathrm{cm}^{3}$ \\
\hline HEDL 3 & PAN1@0.14 g/cm 3 & CPICA & $0.29 \mathrm{~g} / \mathrm{cm}^{3}$ \\
\hline HEDL 4 & PAN $2 @ 0.17 \mathrm{~g} / \mathrm{cm}^{3}$ & PICA & $0.29 \mathrm{~g} / \mathrm{cm}^{3}$ \\
\hline HEDL 5 & PAN $2 @ 0.17 \mathrm{~g} / \mathrm{cm}^{3}$ & CPICA & $0.31 \mathrm{~g} / \mathrm{cm}^{3}$ \\
\hline
\end{tabular}

* Sample was damaged during setup into the arcjet and was not able to be tested.

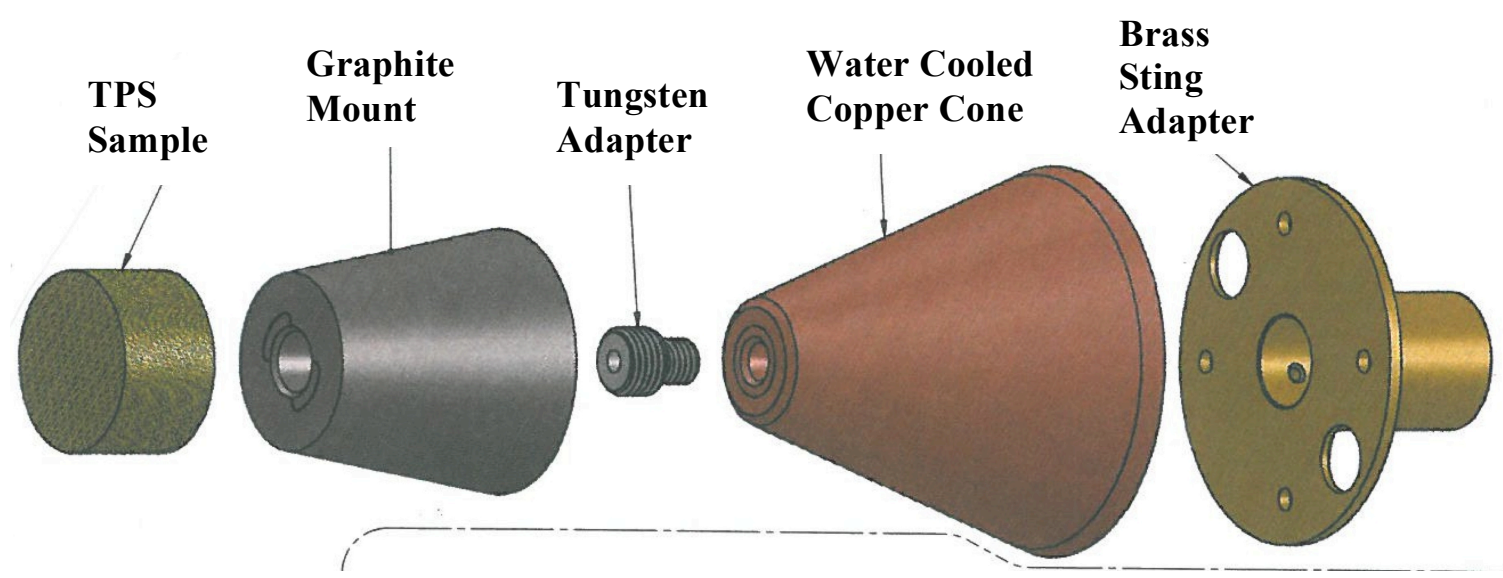

Figure 7. IHF 2-inch diameter arcjet model assembly.

Table 6. Arc heater settings (max facility condition) and anticipated heat flux environment that 2-inch flat face model will experience, based on CFD analysis.

\begin{tabular}{|c|c|c|c|c|c|c|c|c|}
\hline $\begin{array}{c}\text { Cold Wall } \\
\text { Heat Flux } \\
\mathbf{2 - i n ~ F F ~} \\
\left(\mathbf{W} / \mathbf{c m}^{2}\right)\end{array}$ & $\begin{array}{c}\text { Test } \\
\text { Duration } \\
\text { (seconds) }\end{array}$ & $\begin{array}{c}\text { Shear } \\
\text { Centerline } \\
\text { to Edge } \\
\text { (Pa) }\end{array}$ & $\begin{array}{c}\text { Enthalpy } \\
\text { (MJ/kg) }\end{array}$ & $\begin{array}{c}\text { Main } \\
\text { Air } \\
(\mathbf{g m} / \mathbf{s})\end{array}$ & $\begin{array}{c}\text { Add } \\
\text { Air } \\
(\mathbf{g m} / \mathbf{s})\end{array}$ & $\begin{array}{c}\text { Ar } \\
(\mathbf{g m} / \mathbf{s})\end{array}$ & $\begin{array}{c}\text { Arc } \\
\text { Current } \\
(\mathbf{A m p})\end{array}$ & $\begin{array}{c}\text { Dist from } \\
\text { Nozzle } \\
\text { Exit } \\
\text { (inch) }\end{array}$ \\
\hline$\sim 1750$ & $5-10$ & $0-2000$ & 25 & 720 & 55 & 54 & 6000 & 4 \\
\hline
\end{tabular}




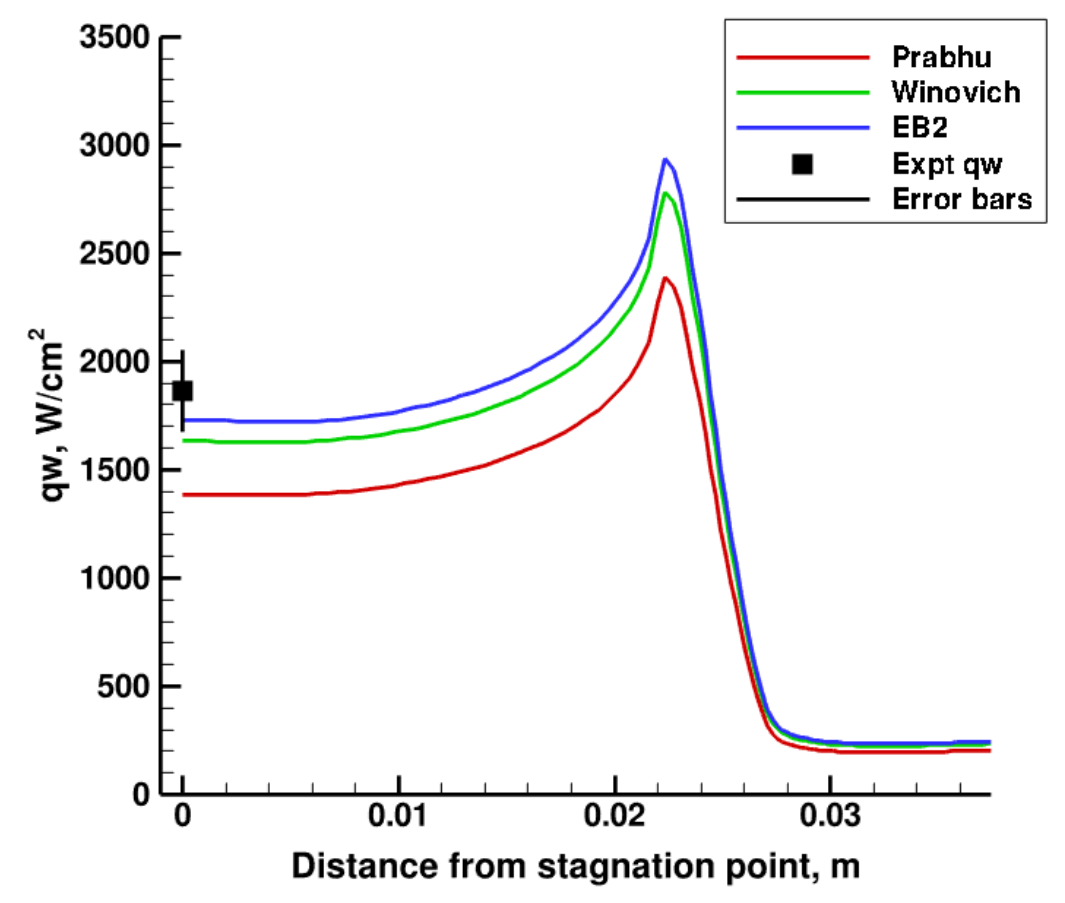

Figure 8. CFD prediction of heating conditions on a 2-inch diameter flat face arcjet model. 

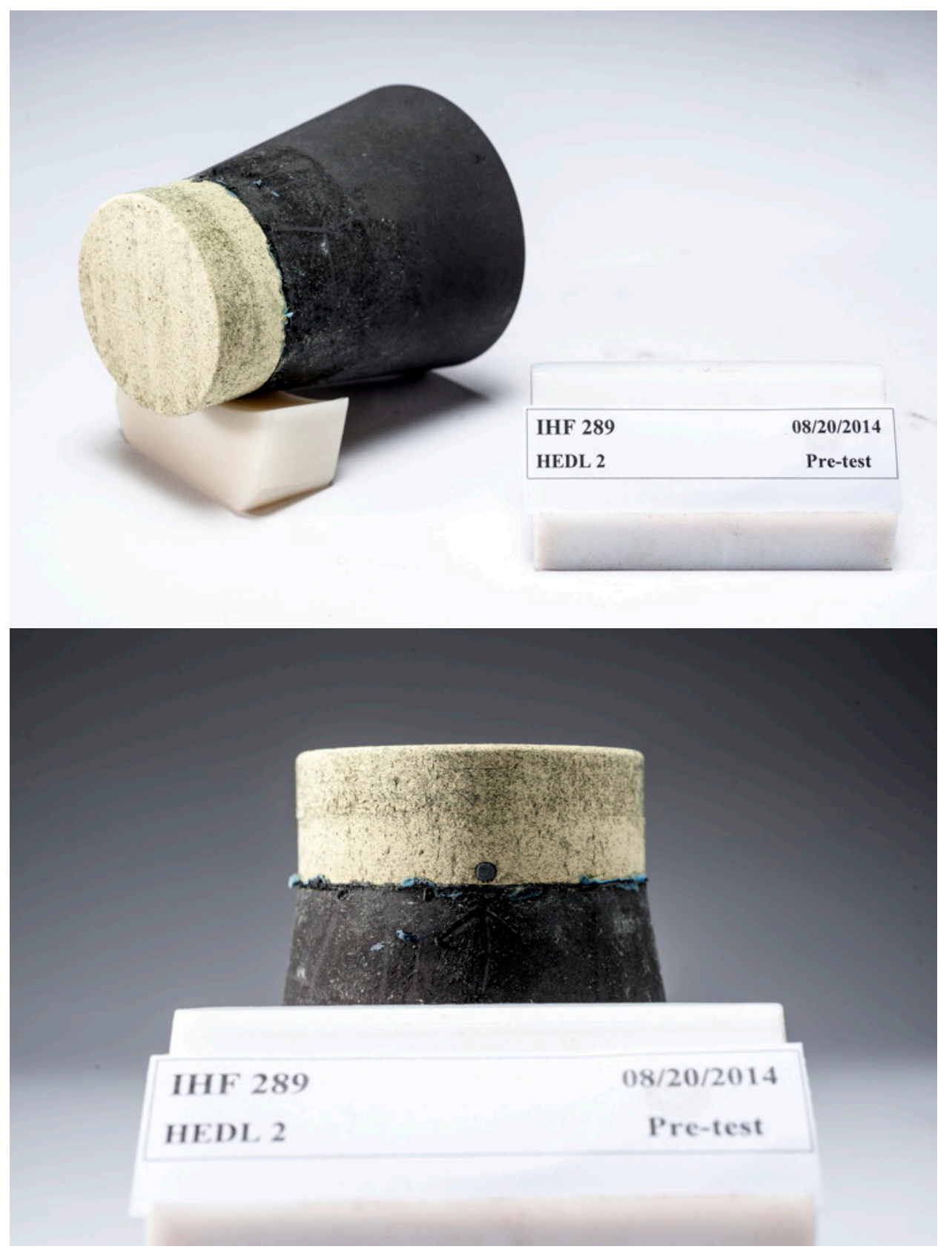

Figure 9. Pre-test photos of a typical 2-inch diameter flat-face arcjet model. 


\section{B. IHF High Heat Flux Test Results}

Five of the 6 models were successfully tested at the prescribed test condition for the full durations without failure. Model 1 was inadvertently damaged during installation into the arcjet facility and was not able to be repaired in time to be tested. An image of a model during testing is shown in Figure 10. Comparison of pre-test CFD to measured calibration the 4-inch IsoQ is listed in Table 7. Representative post-test photographs of the flat-face test models are shown in Figure 11 and Figure 12. All models showed smooth recession without cracks, spallation or other surface defects.

Table 7. Pre-test and actual measured arcjet conditions as referenced to a 4-inch IsoQ copper slug calorimeter.

\begin{tabular}{|c|c|c|c|}
\hline \multicolumn{2}{|c|}{ Pre-Test CFD Estimate } & \multicolumn{2}{|c|}{ Arcjet Measured } \\
\hline $\begin{array}{c}\text { Coldwall Heat } \\
\text { Flux }\left(\mathrm{W} / \mathrm{cm}^{2}\right)\end{array}$ & $\begin{array}{c}\text { Pressure } \\
(\mathrm{atm})\end{array}$ & $\begin{array}{c}\text { Coldwall } \\
\text { Heat Flux } \\
\left(\mathrm{W} / \mathrm{cm}^{2}\right)\end{array}$ & $\begin{array}{c}\text { Pressure } \\
(\mathrm{atm})\end{array}$ \\
\hline $1500-1750$ & 1.3 & 1767 & 1.3 \\
\hline
\end{tabular}

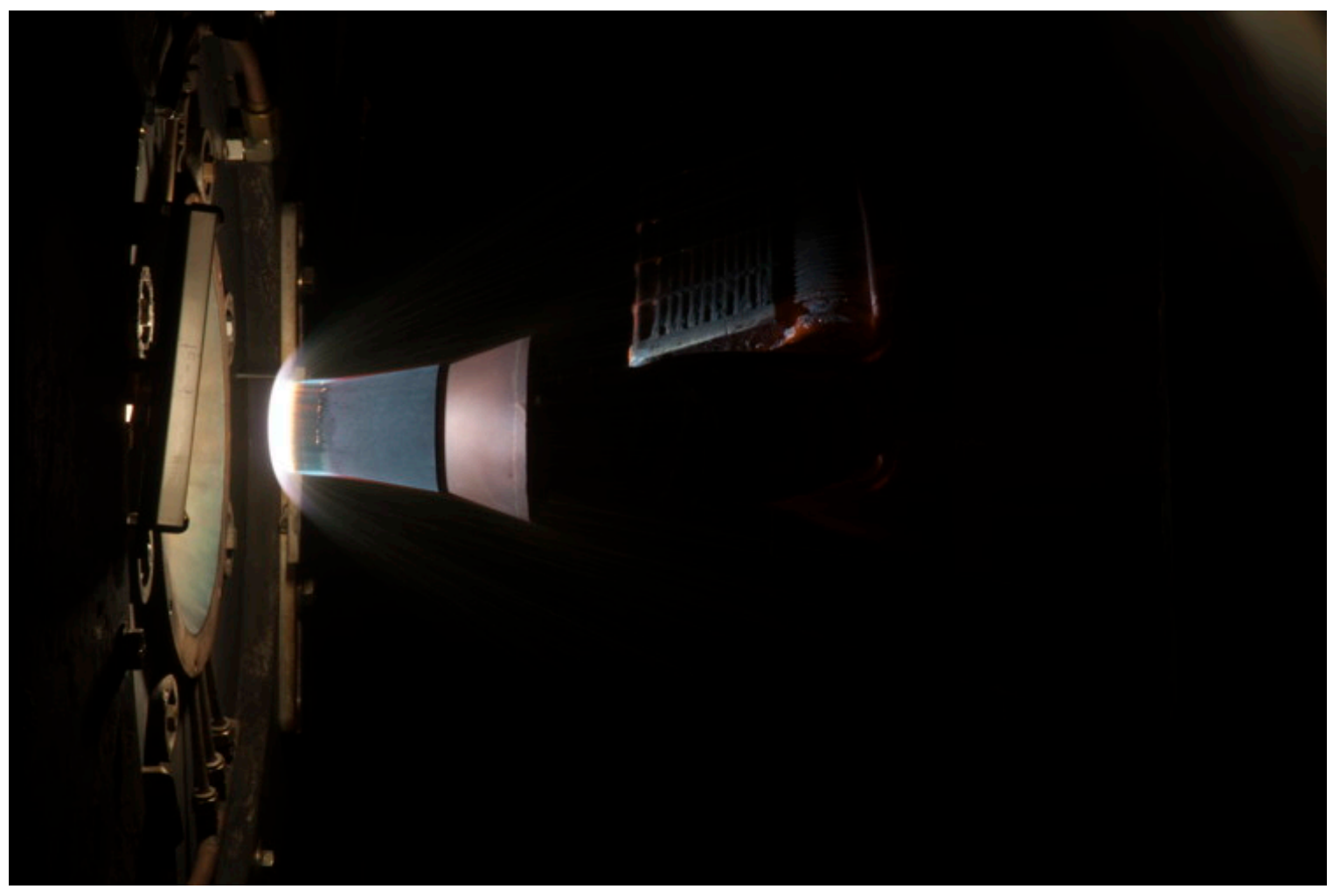

Figure 10. Photo of a 2-inch diameter flat-face model during testing. 


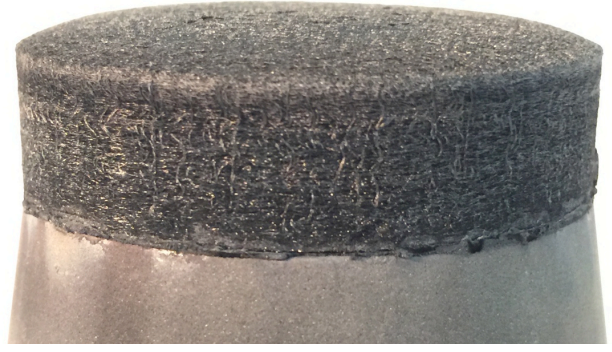

Rayon@0.14 g/ $\mathrm{cm}^{3}$

CPICA Infusion

TPS $0.28 \mathrm{~g} / \mathrm{cm}^{3}$

Duration $10 \mathrm{sec}$.

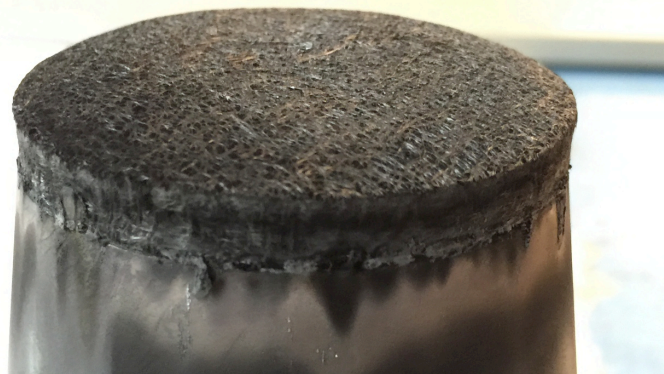

PAN@ 0.14 g/cm ${ }^{3}$

CPICA Infusion

TPS $0.29 \mathrm{~g} / \mathrm{cm}^{3}$

Duration $10 \mathrm{sec}$.

Figure 11. Post-test photos of Rayon and PAN felt arcjet models from a felt with a starting density of $0.14 \mathrm{~g} / \mathrm{cm}^{3}$ and that were infused with phenolic via a CPICA process.

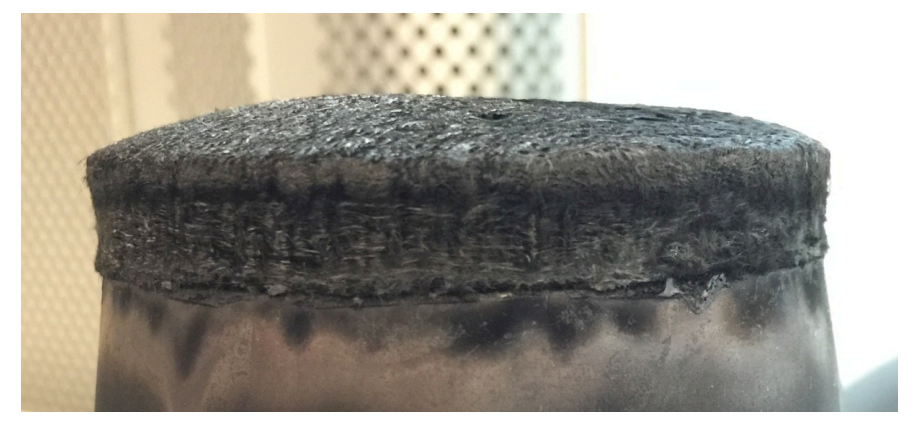

PAN@0.17g/cm

PICA Infusion

TPS $0.29 \mathrm{~g} / \mathrm{cm}^{3}$

Duration $10 \mathrm{sec}$.

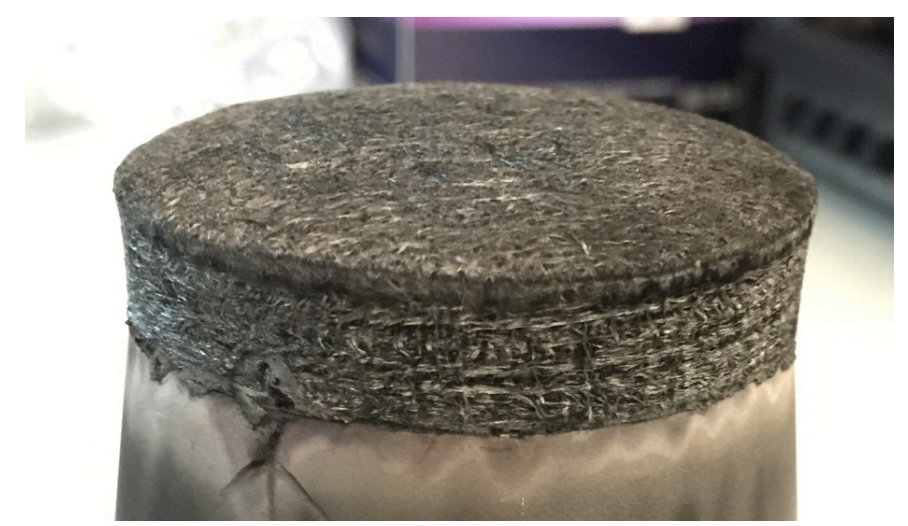

PAN@ $0.17 \mathrm{~g} / \mathrm{cm}^{3}$

CPICA Infusion

TPS $0.30 \mathrm{~g} / \mathrm{cm}^{3}$

Duration $10 \mathrm{sec}$.

Figure 12. Post-test photos of PAN felt arcjet models that were fabricated from felt with a starting density of $0.17 \mathrm{~g} / \mathrm{cm}^{3}$ and were infused with phenolic via a PICA or a CPICA process. 
To measure recession, the surface of each model was measured by using a 3D LASER pre and post-test. Recession measurements were then calculated from a bisecting plane through the center of each model. Surface recession for each model was averaged over the center 1-inch of the model where the heating was most uniform; estimated uncertainty in a measurement is $\pm 0.25 \mathrm{~mm}$. Results are listed in Table 8 and are plotted in Figure 13.

Table 8. Summary of the IHF High Heat Flux test, model infusion and measured recession.

\begin{tabular}{|c|c|c|c|c|c|c|c|}
\hline $\begin{array}{c}\text { Sample } \\
\text { ID }\end{array}$ & Substrate Density & $\begin{array}{c}\text { Resin } \\
\text { Density }\end{array}$ & Infusion & $\begin{array}{c}\text { TPS } \\
\text { Density }\end{array}$ & $\begin{array}{c}\text { Resin to } \\
\text { Fiber \% }\end{array}$ & $\begin{array}{c}\text { Test } \\
\text { Duration }\end{array}$ & $\begin{array}{c}\text { Recession } \\
\text { mm }\end{array}$ \\
\hline $\boldsymbol{1}$ & Rayon@ $0.09 \mathrm{~g} / \mathrm{cm}^{3}$ & $0.20 \mathrm{~g} / \mathrm{cm}^{3}$ & CPICA & $0.29 \mathrm{~g} / \mathrm{cm}^{3}$ & 220 & $\begin{array}{c}\text { Not } \\
\text { Tested }\end{array}$ & $\begin{array}{c}\text { Not } \\
\text { Tested }\end{array}$ \\
\hline $\boldsymbol{2}$ & Rayon @ $0.14 \mathrm{~g} / \mathrm{cm}^{3}$ & $0.14 \mathrm{~g} / \mathrm{cm}^{3}$ & CPICA & $0.28 \mathrm{~g} / \mathrm{cm}^{3}$ & 100 & $10 \mathrm{sec}$ & 1.8 \\
\hline $\mathbf{3}$ & PAN@ $0.14 \mathrm{~g} / \mathrm{cm}^{3}$ & $0.15 \mathrm{~g} / \mathrm{cm}^{3}$ & CPICA & $0.29 \mathrm{~g} / \mathrm{cm}^{3}$ & 110 & $10 \mathrm{sec}$ & 7.0 \\
\hline $\mathbf{4}$ & PAN@ $0.17 \mathrm{~g} / \mathrm{cm}^{3}$ & $0.12 \mathrm{~g} / \mathrm{cm}^{3}$ & PICA & $0.29 \mathrm{~g} / \mathrm{cm}^{3}$ & 70 & $10 \mathrm{sec}$ & 3.0 \\
\hline $\mathbf{5}$ & PAN@ $0.17 \mathrm{~g} / \mathrm{cm}^{3}$ & $0.13 \mathrm{~g} / \mathrm{cm}^{3}$ & CPICA & $0.30 \mathrm{~g} / \mathrm{cm}^{3}$ & 70 & $10 \mathrm{sec}$ & 0.7 \\
\hline
\end{tabular}

As expected, all models experienced slightly more recession at the model edge where heat flux and shear increase rapidly as the flow accelerates to meet the free stream. After 10 seconds in the flow, the Rayon model experienced less than $2 \mathrm{~mm}$ of recession whereas the PAN model of similar substrate and resin density saw recession of $\sim 7 \mathrm{~mm}$. PAN models 4 and 5 were fabricated from a felt with a higher starting density and as expected their recession was less than that of Model 3.

8

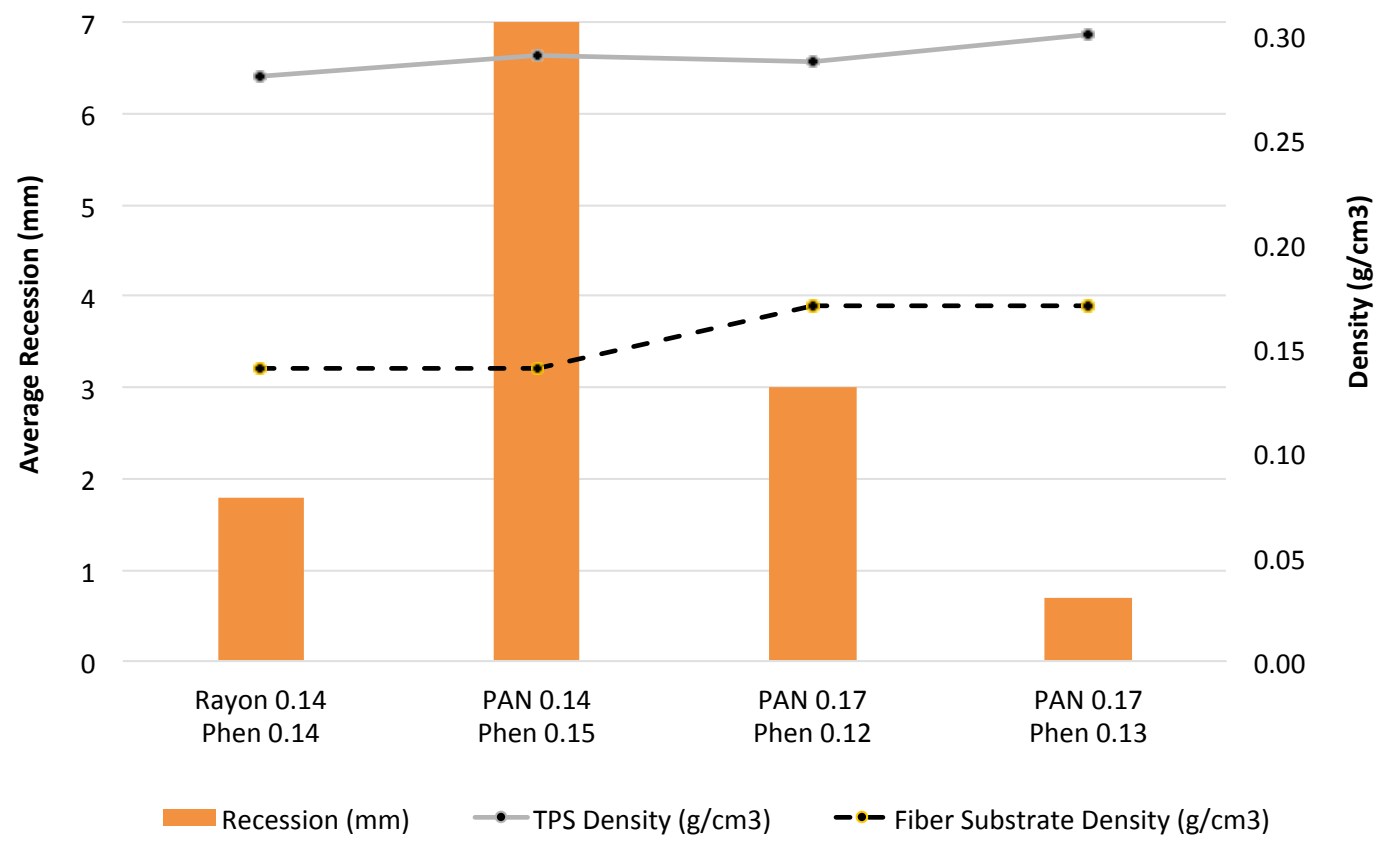

Figure 13. Post test recession comparison of CPICA rayon and PAN models tested in IHF at $1750 \mathrm{~W} / \mathrm{cm}^{2}$. 


\section{IHF SPRITE Shear Testing}

\section{A. IHF SPRITE Test Description}

This test series consisted of 1 day in the IHF facility with the 13 -inch diameter nozzle. A description of the TPS materials tested in this campaign are listed in Table 9 and Table 10. Unlike the previous test series, for this campaign every TPS sample was instrumented with in-depth thermocouples to assist in the comparison of the thermal response of these materials with SoA CPICA and PICA.

Table 9. PAN-based carbon felt SPIRTE model test section descriptions.

\begin{tabular}{|c|c|c|c|c|c|}
$\begin{array}{c}\text { Sample } \\
\text { ID }\end{array}$ & Substrate Density & $\begin{array}{c}\text { Resin } \\
\text { Density }\end{array}$ & Infusion & $\begin{array}{c}\text { TPS } \\
\text { Density }\end{array}$ & $\begin{array}{c}\text { Resin to } \\
\text { Fiber \% }\end{array}$ \\
\hline $\boldsymbol{1}$ & PAN $@ 0.14 \mathrm{~g} / \mathrm{cm}^{3}$ & $0.10 \mathrm{~g} / \mathrm{cm}^{3}$ & PICA & $0.24 \mathrm{~g} / \mathrm{cm} 3$ & 70 \\
\hline $\mathbf{2}$ & PAN $@ 0.14 \mathrm{~g} / \mathrm{cm}^{3}$ & $0.11 \mathrm{~g} / \mathrm{cm}^{3}$ & PICA & $0.25 \mathrm{~g} / \mathrm{cm} 3$ & 80 \\
\hline $\mathbf{3}$ & PAN $@ 0.14 \mathrm{~g} / \mathrm{cm}^{3}$ & $0.15 \mathrm{~g} / \mathrm{cm}^{3}$ & CPICA & $0.29 \mathrm{~g} / \mathrm{cm} 3$ & 110 \\
\hline $\mathbf{4}$ & PAN $@ 0.17 \mathrm{~g} / \mathrm{cm}^{3}$ & $0.12 \mathrm{~g} / \mathrm{cm}^{3}$ & PICA & $0.29 \mathrm{~g} / \mathrm{cm} 3$ & 70 \\
\hline
\end{tabular}

Table 10. Rayon-based carbon felt SPIRTE model test section descriptions.

\begin{tabular}{|c|c|c|c|c|c|}
\hline $\begin{array}{c}\text { Sample } \\
\text { ID }\end{array}$ & Substrate & $\begin{array}{c}\text { Resin } \\
\text { Density }\end{array}$ & Infusion & $\begin{array}{c}\text { TPS } \\
\text { Density }\end{array}$ & $\begin{array}{l}\text { Resin to } \\
\text { Fiber \% }\end{array}$ \\
\hline 1 & Rayon@ @0.09 g/ $\mathrm{cm}^{3}$ & $0.13 \mathrm{~g} / \mathrm{cm}^{3}$ & PICA & $0.22 \mathrm{~g} / \mathrm{cm}^{3}$ & 140 \\
\hline 2 & Rayon@0.09 g/cm 3 & $0.20 \mathrm{~g} / \mathrm{cm}^{3}$ & CPICA & $0.29 \mathrm{~g} / \mathrm{cm}^{3}$ & 220 \\
\hline 3 & Rayon@0.09 g/ $\mathrm{cm}^{3}$ & $0.20 \mathrm{~g} / \mathrm{cm}^{3}$ & CPICA & $0.29 \mathrm{~g} / \mathrm{cm}^{3}$ & 220 \\
\hline 4 & Rayon@0.14 g/cm ${ }^{3}$ & $0.14 \mathrm{~g} / \mathrm{cm}^{3}$ & PICA & $0.28 \mathrm{~g} / \mathrm{cm}^{3}$ & 100 \\
\hline
\end{tabular}

\section{SPRITE Test Model Compositions}

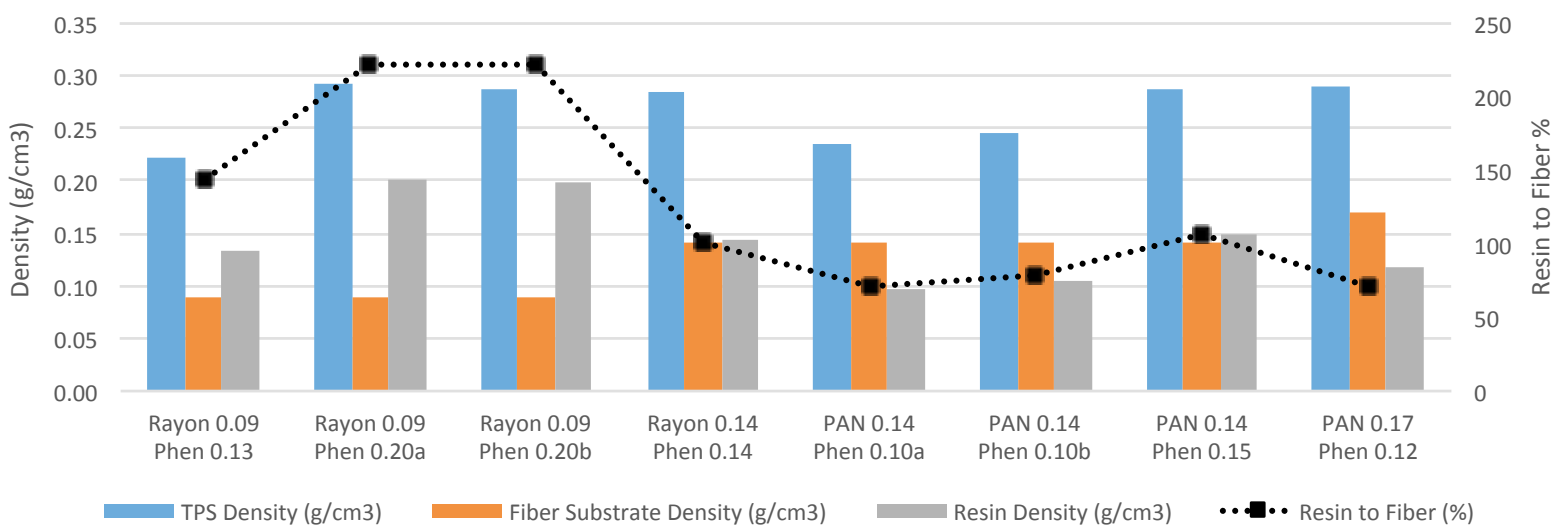

Figure 14. Comparison of substrate density vs. resin density and resulting TPS density.

Figure 14 shows the composition of the test models in terms of the substrate, the resin and the final density, as well as the mass percentage of the pyrolyzing phenolic resin to the reinforcing carbon fiber substrate. The test materials included three carbon fiber substrate densities, two for each material type of Rayon-based or PAN-based fibers, with a factor of three variation from highest to lowest percentage of resin impregnation. The phenolic resin impregnations ranging from 0.01 to $0.20 \mathrm{~g} / \mathrm{cm}^{3}$. Two pairs of closely matched test materials, with computed phenolic resin impregnation pickup within $0.01 \mathrm{~g} / \mathrm{cm}^{3}$ (representing 5 to $10 \%$ of the resin density), are distinguished by the letter $\mathrm{a}$ and $\mathrm{b}$, for material reproducibility. The average percentage of resin to substrate density ratio was $170 \%$ in the rayon-based materials, and an average $70 \%$ for the PAN based materials. There were two pairs of closely matched test materials, having computed phenolic resin impregnation pickup within $0.01 \mathrm{~g} / \mathrm{cm}^{3}$. 
Figure 15 shows two views of the SPRITE test article. For this testing, the initial nose radius, frustum angle, shoulder radius, and diameter were $7.62 \mathrm{~cm}, 55 \mathrm{deg}, 2.032 \mathrm{~cm}$, and $18.7 \mathrm{~cm}$, respectively. The SPRITE model accommodates four frustum test samples with thermocouple (TC) plugs and one uninstrumented nose-cap sample. The thermocouple plugs are located approximately midway along the frustum. Thermocouple plugs were manufactured from the same TPS material used in each frustum segment of the SPRITE model. Two type-K thermocouples were installed at depths of $3.81(0.15$-in) and $7.62 \mathrm{~mm}(0.30$-in) beneath the exposed surface. These thermocouples are denoted as TC1 and TC2, respectively. A third type-K thermocouple (TC3) at $12.7 \mathrm{~mm}(0.50$-in) was bonded on the LI-2200 substructure at the back of each TPS sample. The TPS materials were bonded together and to the substructure using RTV560 adhesive. Different versions of CPICA vary in color, but this variation does not affect ablative or thermal performance.

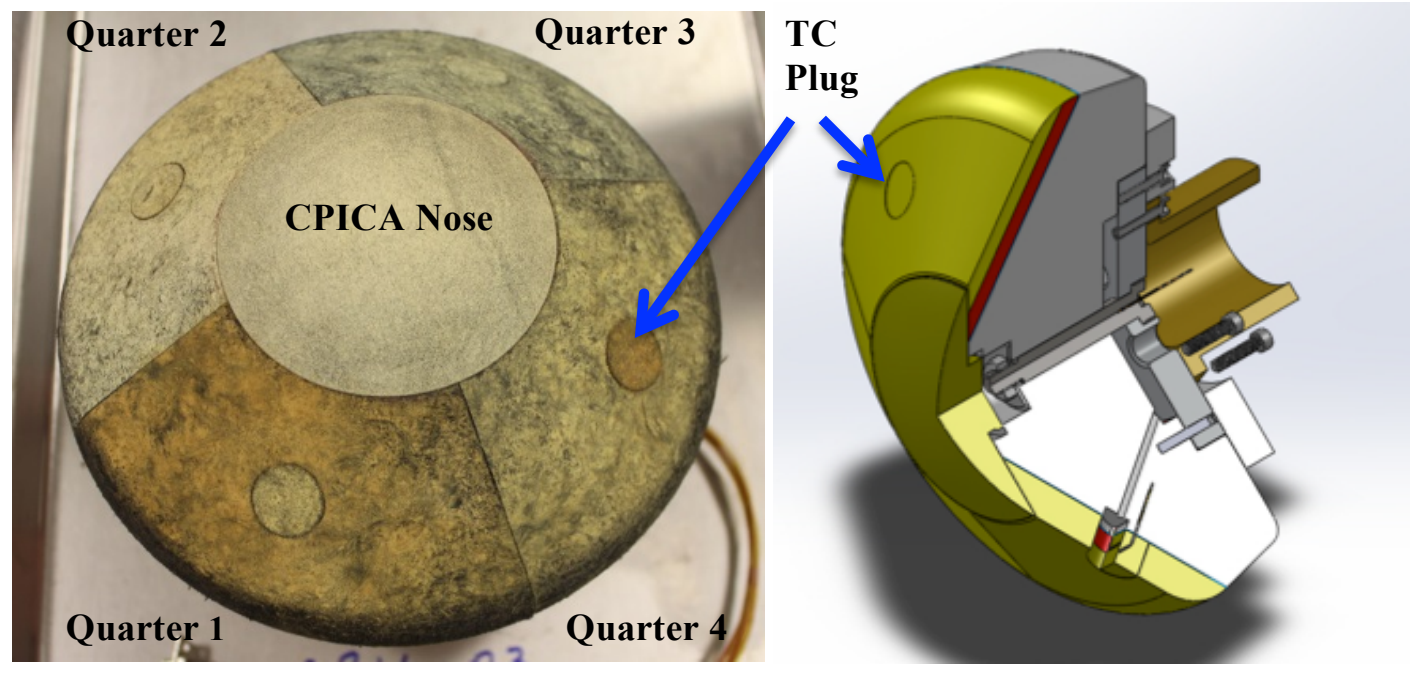

Figure 15. Image of SPRITE test article assembled with different CPICA concepts and a cross-section of how the arcjet model is assembled showing location of instrumentation plugs.

For all test conditions, a dual-instrument calibration model ( $4 \mathrm{in}$. hemisphere) was inserted to the centerline to measure the stagnation point pressure and cold-wall heat flux. While standard practice is to use a calorimeter with the same shape as the test article, the arcjet facility does not have a large calibration model with a SPRITE geometry. ${ }^{7}$ The test gas was an air/argon mixture containing approximately $8 \%$ argon by mass. For each condition, based on the calorimeter measurements and arcjet run parameters, the flowfield through the nozzle and around the calibration model was calculated using the DPLR code. ${ }^{8}$ Then, a second DPLR solution was obtained for the SPRITE geometry with the same nozzle flow conditions. Table 11 summarizes the two test conditions of interest. The DPLR-predicted environments in Table 11 describe the unablated SPRITE model at the stagnation point and at the center of the frustum TC plug. The heat flux has a local maximum near the frustum-shoulder tangency point. The magnitude of the shear is 50 to $200 \mathrm{~Pa}$ on the frustum near the TC plug and up to $500 \mathrm{~Pa}$ on the shoulder. Plots of CFD computed heating, shear and pressure for the two conditions are show in Figures 16 and 17. Expected radial heat flux, pressure, shear, and surface temperature distributions for the SPRITE shape were determined from CFD analysis and are listed in listed in Table 12

Table 11. Heating environment as measured from a 4-inch hemi calorimeter.

\begin{tabular}{|l|c|c|c|c|c|c|c|c|} 
& $\begin{array}{c}\text { Cold Wall } \\
\text { Heat Flux } \\
\text { 4-in Hemi } \\
\left(\mathrm{W} / \mathrm{cm}^{2}\right)\end{array}$ & $\begin{array}{c}\text { Stagnation } \\
\text { Pressure } \\
(\mathrm{atm})\end{array}$ & $\begin{array}{c}\text { Enthalpy } \\
(\mathrm{MJ} / \mathrm{kg})\end{array}$ & $\begin{array}{c}\text { Main } \\
\text { Air } \\
(\mathrm{gm} / \mathrm{s})\end{array}$ & $\begin{array}{c}\text { Add } \\
\text { Air } \\
(\mathrm{gm} / \mathrm{s})\end{array}$ & $\begin{array}{c}\text { Ar } \\
(\mathrm{gm} / \mathrm{s})\end{array}$ & $\begin{array}{c}\text { Arc } \\
\text { Current } \\
(\mathrm{Amp})\end{array}$ & $\begin{array}{c}\text { Dist from } \\
\text { Nozzle Exit } \\
(\text { in })\end{array}$ \\
\hline Condition 1 & 900 & 0.32 & 27 & 740 & 55 & 54 & 6000 & \multirow{2}{*}{10} \\
\hline Condition 2 & 400 & 0.19 & 17 & 270 & 330 & 42 & 3500 & 10 \\
\hline
\end{tabular}


Table 12. SPRITE Test Conditions. Heating environment based on CFD analysis.

\begin{tabular}{|c|c|c|c|c|c|c|}
\hline & \multirow{2}{*}{$\begin{array}{c}\text { Test } \\
\text { Duration } \\
\text { (seconds) }\end{array}$} & \multicolumn{2}{|c|}{ Stagnation } & \multicolumn{3}{|c|}{ Frustrum } \\
\hline & & $\begin{array}{c}\text { Heat Flux } \\
\left(\mathrm{W} / \mathrm{cm}^{2}\right)\end{array}$ & $\begin{array}{c}\text { Pressure } \\
\text { (atm) }\end{array}$ & $\begin{array}{c}\text { Heat Flux } \\
\left(\mathrm{W} / \mathrm{cm}^{2}\right)\end{array}$ & $\begin{array}{c}\text { Pressure } \\
\text { (atm) }\end{array}$ & $\begin{array}{c}\text { Shear } \\
\text { (Pa) }\end{array}$ \\
\hline Condition 1 & 30 & 730 & 0.3 & 400 & 0.25 & 180 \\
\hline Condition 2 & 60 & 338 & 0.2 & 180 & 0.14 & 120 \\
\hline
\end{tabular}
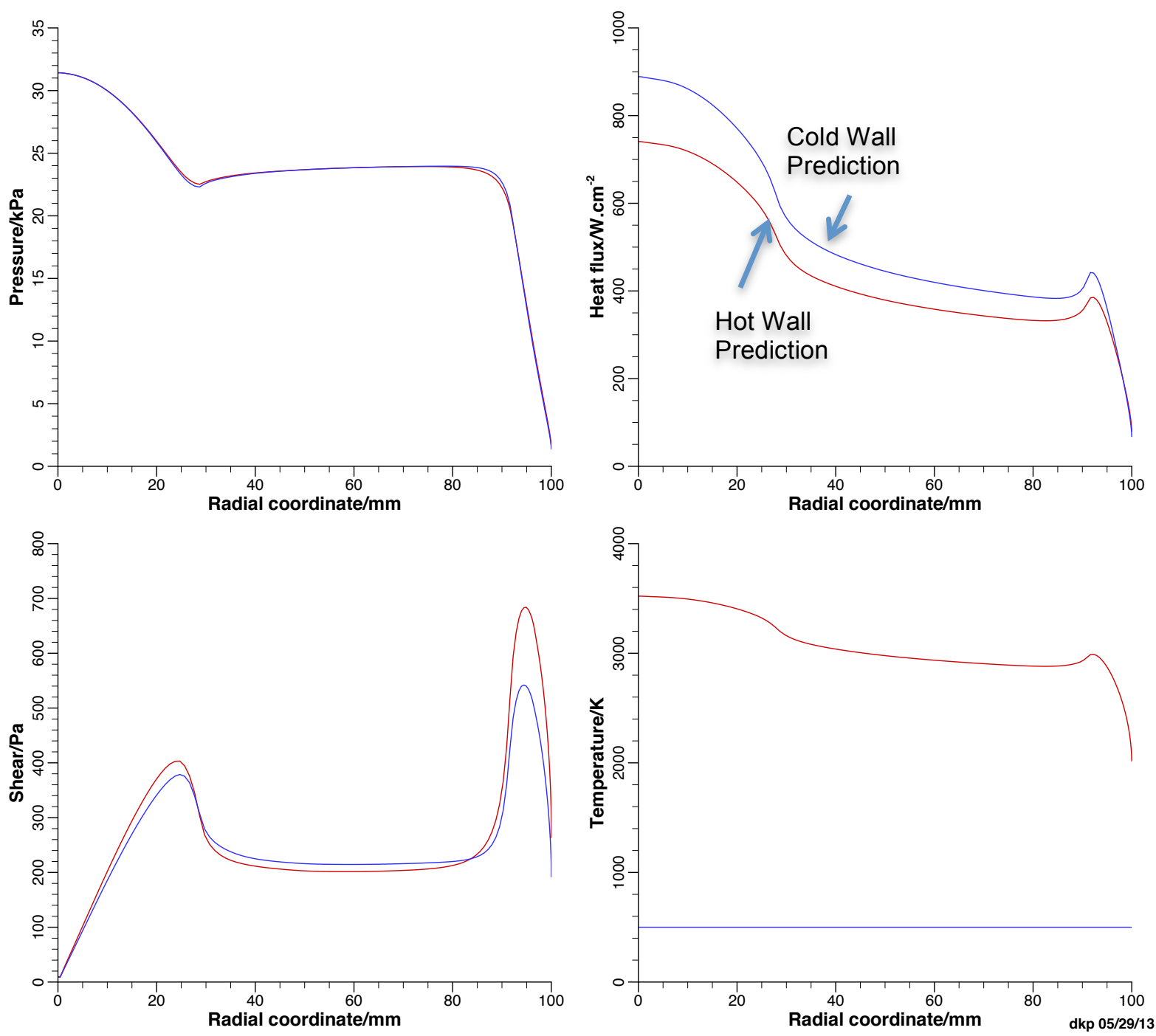

Figure 16. CFD predictions for Condition $1\left(400 \mathrm{~W} / \mathrm{cm}^{2}\right)$. 

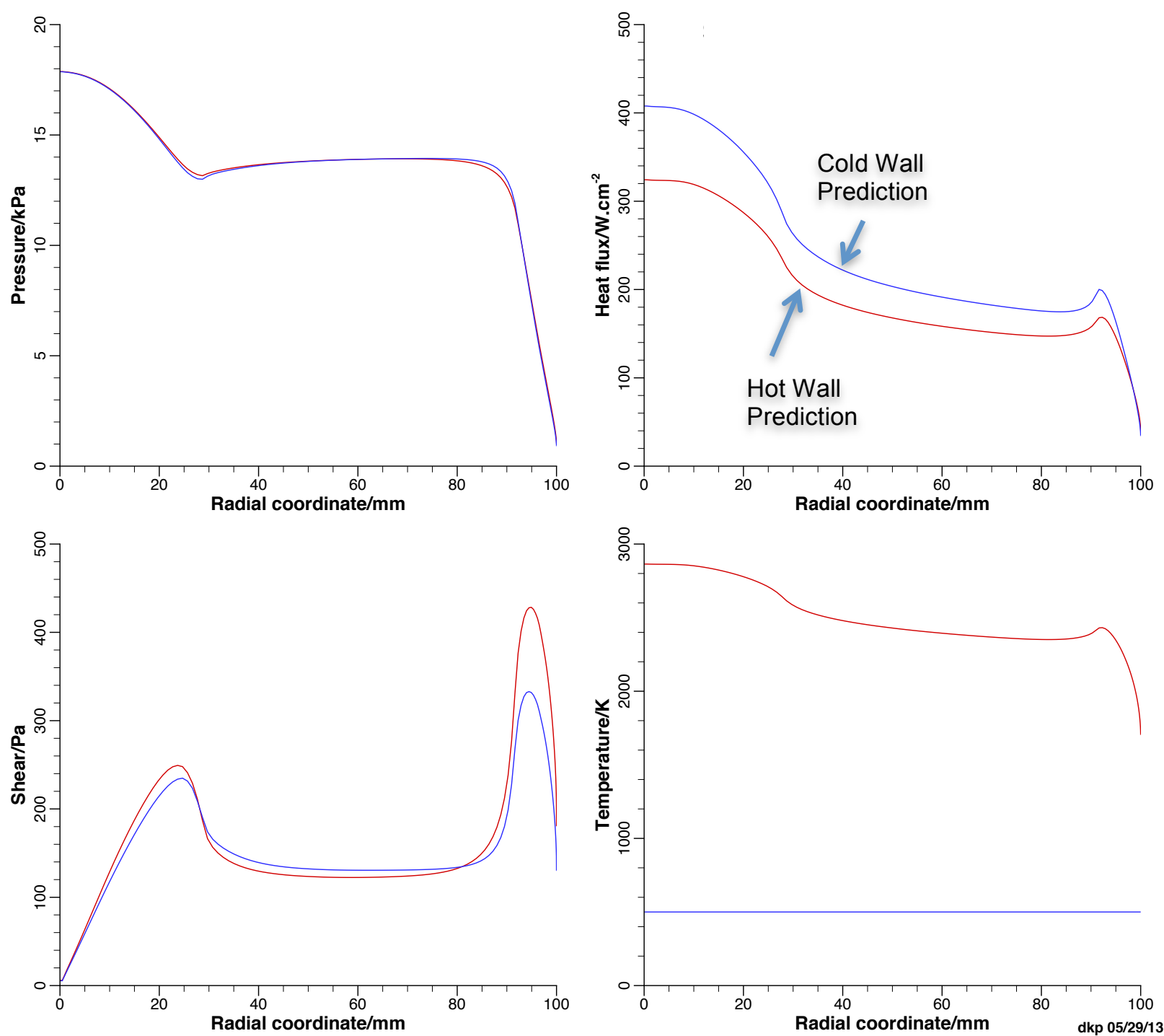

Figure 17. CFD predictions for Condition $2\left(180 \mathrm{~W} / \mathrm{cm}^{2}\right)$.

\section{B. IHF SPRITE Test Results}

All 4 models were successfully tested at the 2 prescribed test conditions for the full durations without failure. Comparison of pre-test heat flux estimates to post-test measured calibration data is listed in Table 13 for each condition. An image of a model during testing is shown in Figure 18. Post-test photographs of the SPRITE models are shown in Figures 19-22.

Table 13. Pre-test and actual measured arcjet conditions

as referenced to a 4-inch hemisphere copper calorimeter.

\begin{tabular}{|c|c|c|c|c|}
\hline & \multicolumn{2}{|c|}{ Pre-Test CFD Est. } & \multicolumn{2}{c|}{ Arcjet Measured } \\
\cline { 2 - 5 } & $\begin{array}{c}\text { Coldwall Heat } \\
\text { Flux }\left(\mathrm{W} / \mathrm{cm}^{2}\right)\end{array}$ & $\begin{array}{c}\text { Pressure } \\
(\mathrm{atm})\end{array}$ & $\begin{array}{c}\text { Coldwall Heat } \\
\text { Flux }\left(\mathrm{W} / \mathrm{cm}^{2}\right)\end{array}$ & $\begin{array}{c}\text { Pressure } \\
(\mathrm{atm})\end{array}$ \\
\hline Condition 1 & 900 & 0.32 & 935 & 0.32 \\
\hline Condition 2 & 400 & 0.19 & 400 & 0.17 \\
\hline
\end{tabular}




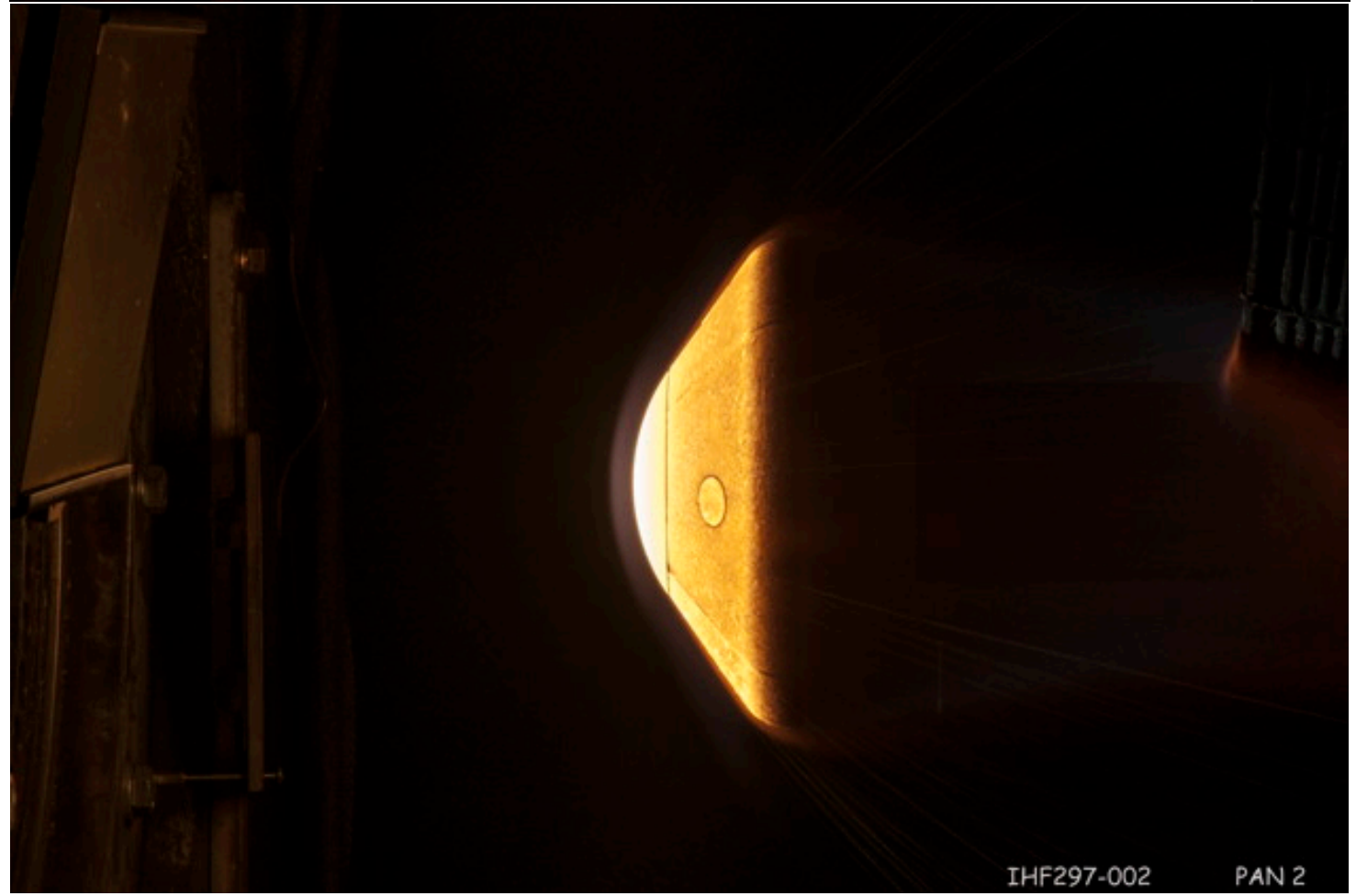

Figure 18. Image of PAN and Rayon SPRITE models during testing at the high condition $\left(400 \mathrm{~W} / \mathrm{cm}^{2}\right)$. 


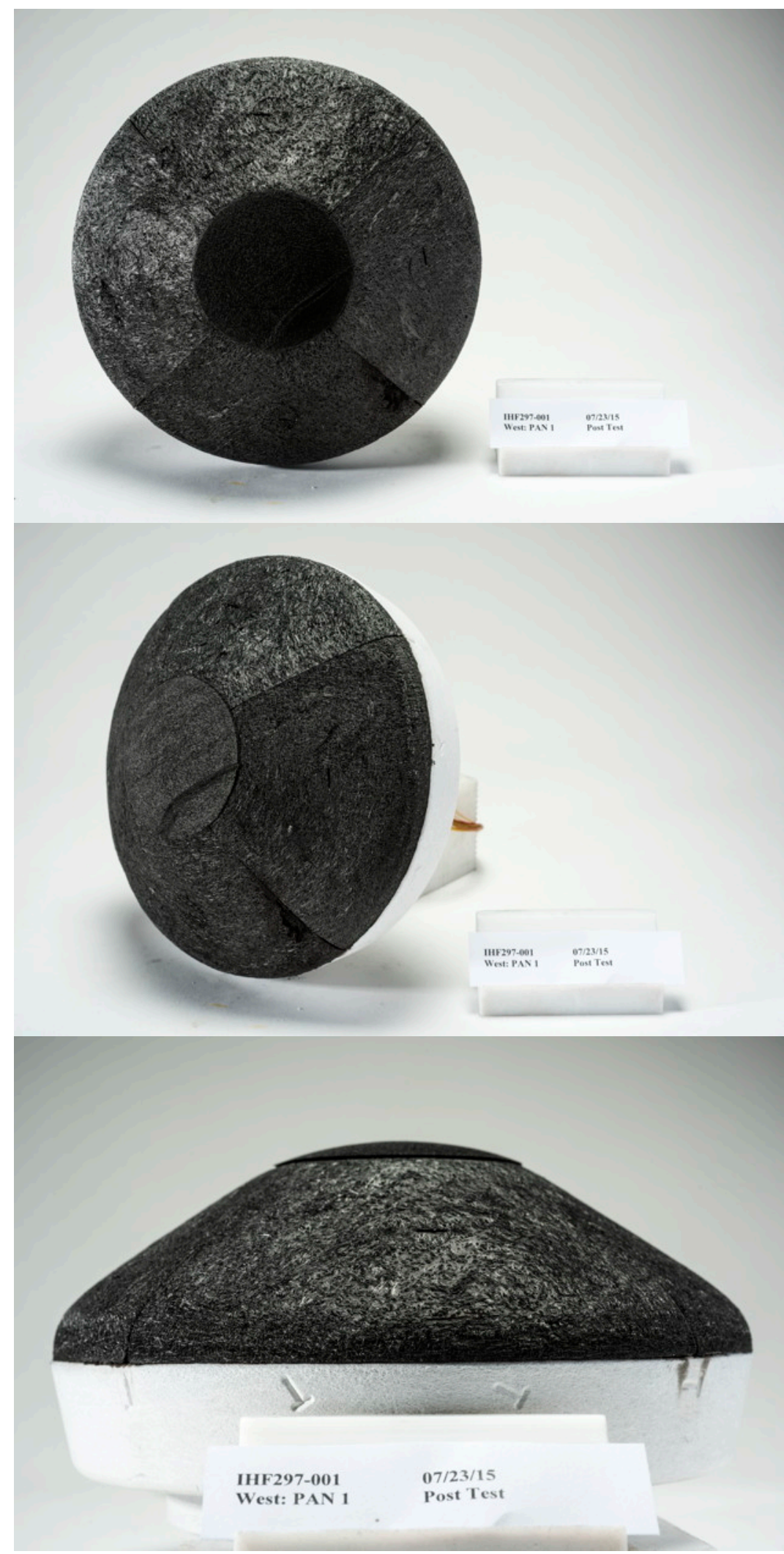

Figure 19. Post-test photo of the PAN SPRITE model after 30 seconds at $400 \mathrm{~W} / \mathrm{cm}^{2}$. 


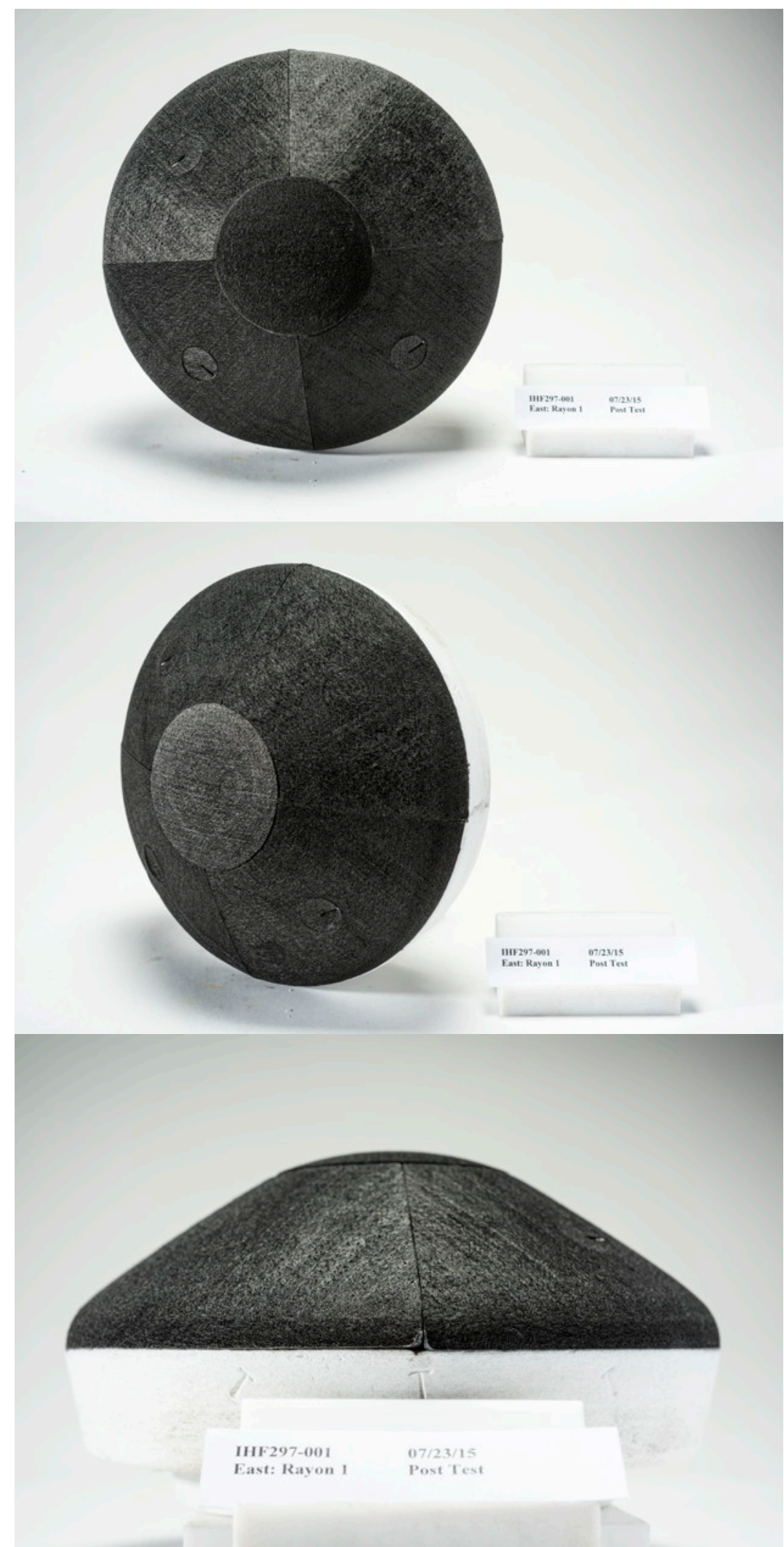

Figure 20. Post-test photo of the Rayon SPRITE model after 30 seconds at $400 \mathrm{~W} / \mathrm{cm}^{2}$. 


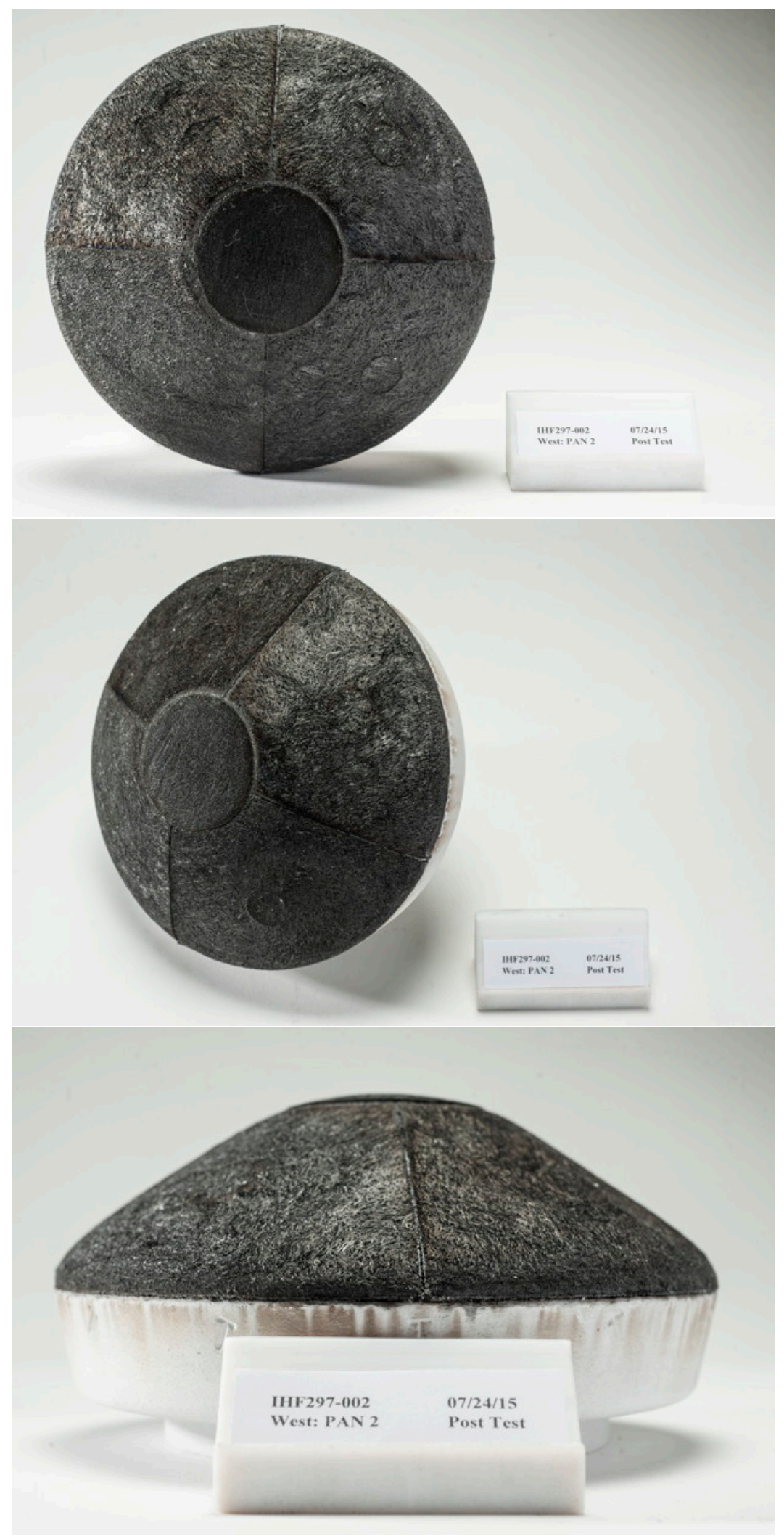

Figure 21. Post-test photo of the PAN SPRITE model after 60 seconds at $180 \mathrm{~W} / \mathrm{cm}^{2}$. 


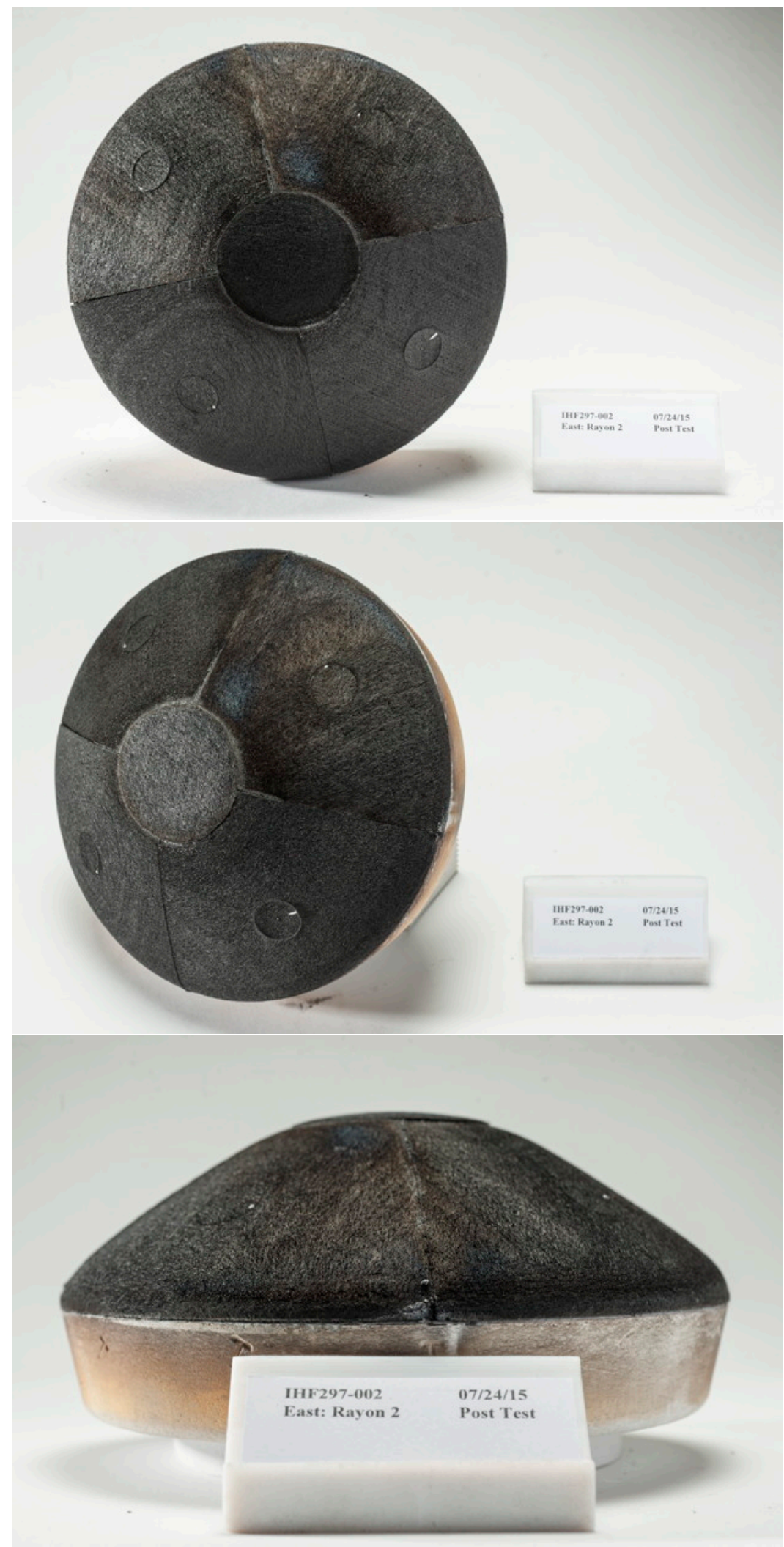

Figure 22. Post-test photo of the Rayon SPRITE model after 60 seconds at $180 \mathrm{~W} / \mathrm{cm}^{2}$ 
Surface temperature and in-depth TC measurements were successfully obtained for each of the 4 TPS gores on each SPRITE model. At the high condition PAN and Rayon models had similar surface temperatures of $\sim 2350 \mathrm{C}$ and at the low condition, all models also had similar surface temperatures of $\sim 1925 \mathrm{C}$. An example of the temperature histories captured by various in-depth thermocouples is shown in Figure 23 for both PAN and Rayon models that were tested at $400 \mathrm{~W} / \mathrm{cm}^{2}$. As expected, the in-depth and back-face temperatures of both rayon-based SPRITE models were 50\% lower than the PAN-based models. TC traces for the other models showed similar trends.

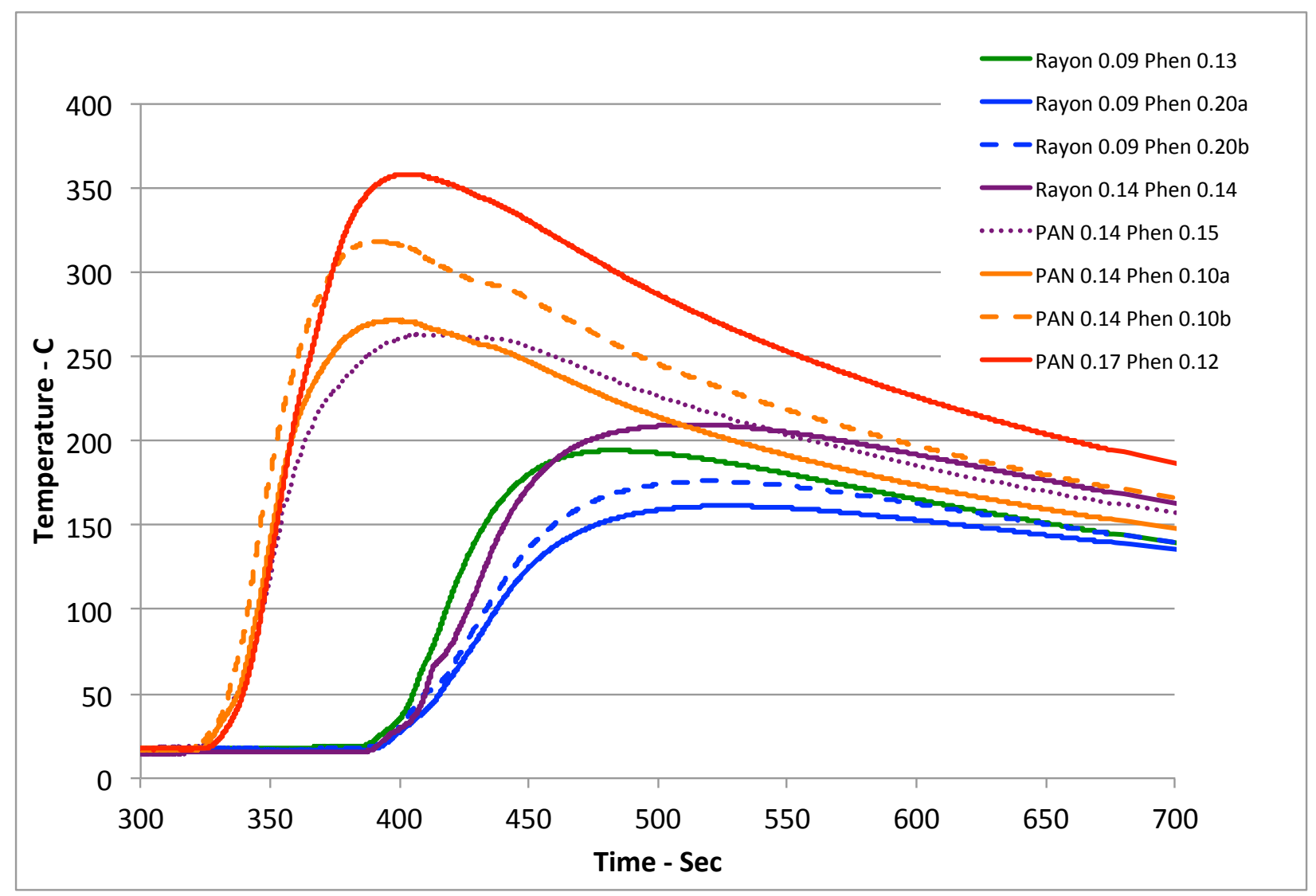

Figure 23. Comparison of bondline TC responses from each of the 4 TPS sections in both the PAN and Rayon SPRITE models that were tested at $400 \mathrm{~W} / \mathrm{cm}^{2}$ for 30 seconds.

A plot of the peak bondline temperatures for the two types of materials at both heat fluxes is shown in Figure 24 (and is summarized in Table 14 and 15). For all materials, lower bondline temperatures at the higher flux tests indicated more efficient ablation performance. It can be observed that the lowest measured bondline temperatures, were from the lowest density substrate $0.09 \mathrm{~g} / \mathrm{cm}^{3}$ Rayon, with the highest resin loading of $0.20 \mathrm{~g} / \mathrm{cm}^{3}$ or $220 \%$. The second lowest bondline temperatures were tied between the two other rayon compositions low and high density substrates with similar resin loadings. This unexpected insensitivity to the rayon substrate density is believed due to the thermal behavior being dominated by the relatively high pyrolyzng resin loading. For the PAN materials with the $0.14 \mathrm{~g} / \mathrm{cm}^{3}$ substrate, bondline temperatures decreased with added resin. The PAN-based substrates showed the expected increased bondline temperature with increased substrate density from 0.14 to $0.17 \mathrm{~g} / \mathrm{cc}$, unlike the rayonbased samples. 


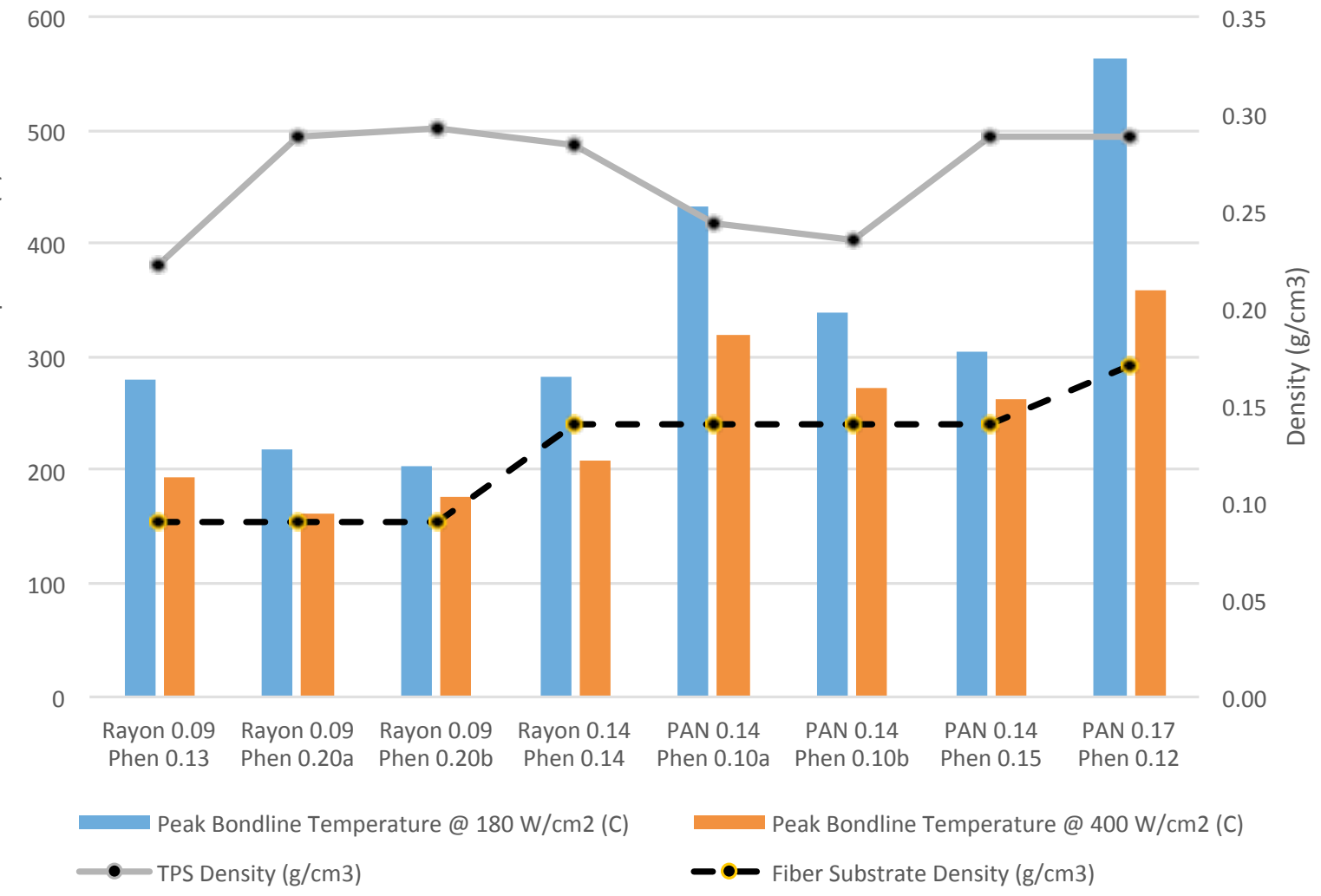

Figure 24. Plot of peak bondline temperature for the PAN and Rayon TPS samples tested in the SPRITE models at $180 \mathrm{~W} / \mathrm{cm} 2$ (for 60 seconds) and $400 \mathrm{~W} / \mathrm{cm} 2$ (for 30 seconds).

To measure recession, the surface of each model was measured in 3D using a LASER scanner. Pre and post-test images were overlayed to compute average recession in the flank section over the location where the TC plug was situated. Recession measurements were then calculated from a bisecting plane through the TC location of each TPS quadrant as illustrated in Figure 25 below. Estimated uncertainty in a measurement is $\pm 0.25 \mathrm{~mm}$.

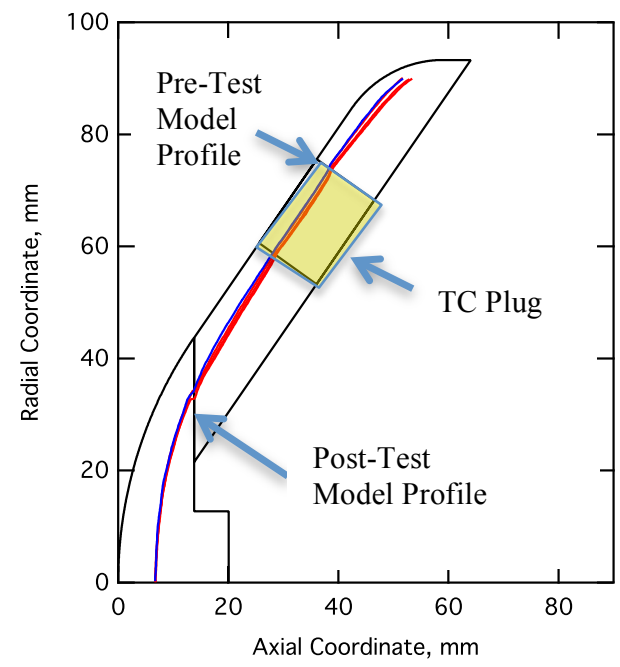

Figure 25. Example of the comparison of pre- and post-test

LASER measured surface profiles for a TPS quadrant on a SPRITE model. 
Figure 26 shows the recession measurements made on the test models. The recession measurements show several trends. Recession did not really decrease when using a substrate, rayon or PAN, with higher density. But, recession did seem to decrease in both fiber substrate systems when a higher resin loading was used. In fact, both of the samples with the higher density PAN and Rayon substrates had slightly higher recession than the lower density substrates which had more phenolic resin.

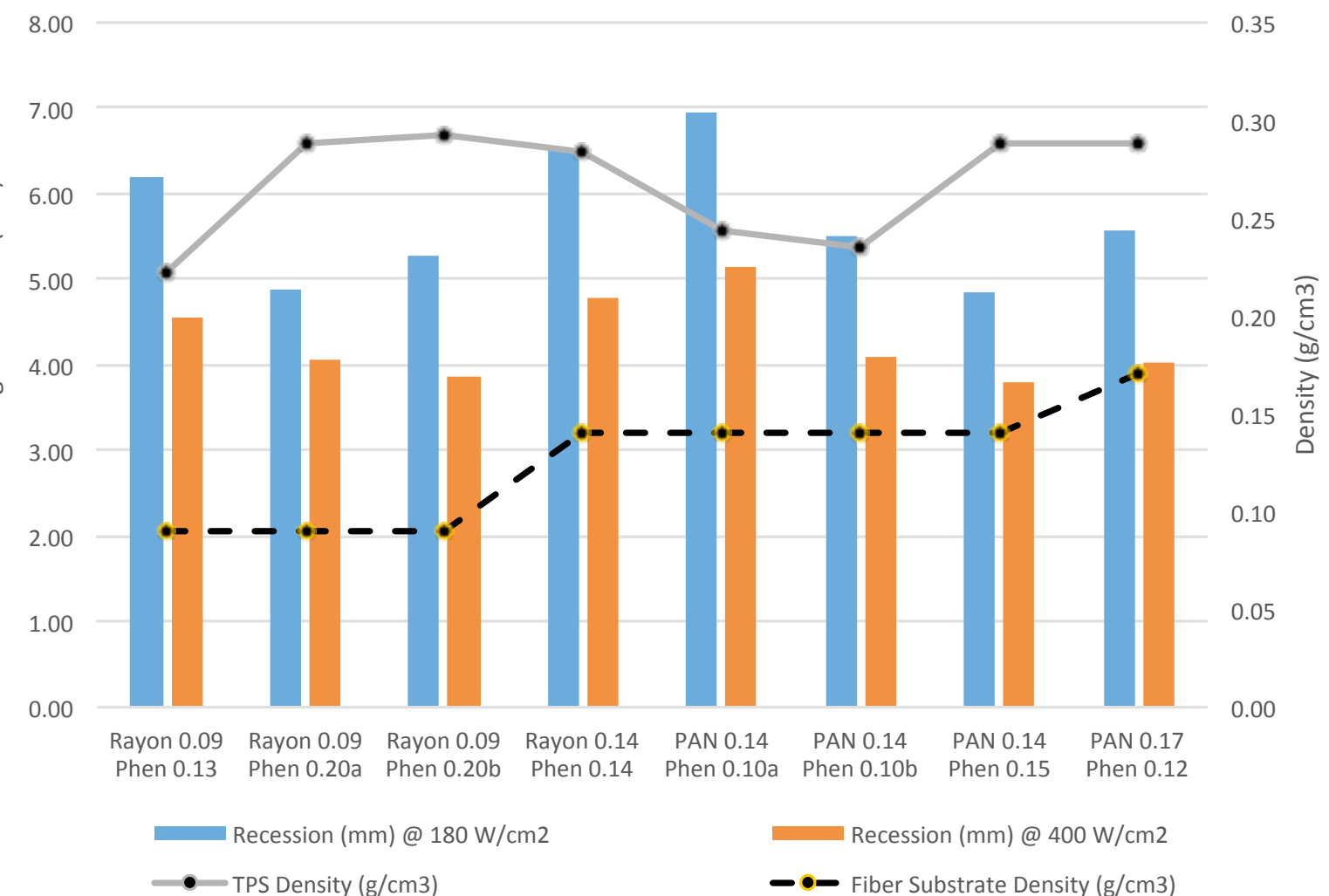

Figure 26. Plot recession for the PAN and Rayon TPS samples tested in the SPRITE models at 180 (for 60 seconds) and $400 \mathrm{~W} / \mathrm{cm} 2$ (for 30 seconds). 
Table 14. Summary of average bondline temperature measurements between PAN TPS sections.

\begin{tabular}{|c|l|c|c|c|c|c|c|}
\hline $\begin{array}{c}\text { Sample } \\
\text { ID }\end{array}$ & Substrate Density & $\begin{array}{c}\text { Resin } \\
\text { Density }\end{array}$ & Infusion & $\begin{array}{c}\text { TPS } \\
\text { Density }\end{array}$ & $\begin{array}{c}\text { Resin to } \\
\text { Fiber \% }\end{array}$ & $\begin{array}{c}\text { Bondline } \\
{ }^{\mathbf{C}}\end{array}$ & $\begin{array}{c}\text { Recession } \\
\text { mm }\end{array}$ \\
\hline $\boldsymbol{1}$ & PAN @ $0.14 \mathrm{~g} / \mathrm{cm}^{3}$ & $0.10 \mathrm{~g} / \mathrm{cm}^{3}$ & PICA & $0.24 \mathrm{~g} / \mathrm{cm}^{3}$ & 0.7 & 260 & $5.1 \pm 0.37$ \\
\hline $\mathbf{2}$ & PAN@ $0.14 \mathrm{~g} / \mathrm{cm}^{3}$ & $0.11 \mathrm{~g} / \mathrm{cm}^{3}$ & PICA & $0.25 \mathrm{~g} / \mathrm{cm}^{3}$ & 0.8 & 270 & $4.1 \pm 0.44$ \\
\hline $\mathbf{3}$ & PAN@ $0.14 \mathrm{~g} / \mathrm{cm}^{3}$ & $0.15 \mathrm{~g} / \mathrm{cm}^{3}$ & CPICA & $0.29 \mathrm{~g} / \mathrm{cm}^{3}$ & 1.1 & 320 & $3.8 \pm 0.27$ \\
\hline $\mathbf{4}$ & PAN@ $0.17 \mathrm{~g} / \mathrm{cm}^{3}$ & $0.12 \mathrm{~g} / \mathrm{cm}^{3}$ & PICA & $0.29 \mathrm{~g} / \mathrm{cm}^{3}$ & 0.7 & 360 & $4.0 \pm 0.47$ \\
\hline
\end{tabular}

\begin{tabular}{|c|l|c|c|c|c|c|c|}
\hline $\begin{array}{c}\text { Sample } \\
\text { ID }\end{array}$ & Substrate Density & $\begin{array}{c}\text { Resin } \\
\text { Density }\end{array}$ & Infusion & $\begin{array}{c}\text { TPS } \\
\text { Density }\end{array}$ & $\begin{array}{c}\text { Resin to } \\
\text { Fiber \% }\end{array}$ & $\begin{array}{c}\text { Bondline } \\
{ }^{\mathbf{0}} \mathbf{C}\end{array}$ & $\begin{array}{c}\text { Recession } \\
\text { mm }\end{array}$ \\
\hline $\boldsymbol{1}$ & PAN @ $0.14 \mathrm{~g} / \mathrm{cm}^{3}$ & $0.10 \mathrm{~g} / \mathrm{cm}^{3}$ & PICA & $0.24 \mathrm{~g} / \mathrm{cm}^{3}$ & 0.7 & 300 & $6.9 \pm 0.12$ \\
\hline $\mathbf{2}$ & PAN@ $0.14 \mathrm{~g} / \mathrm{cm}^{3}$ & $0.11 \mathrm{~g} / \mathrm{cm}^{3}$ & PICA & $0.25 \mathrm{~g} / \mathrm{cm}^{3}$ & 0.8 & 340 & $5.5 \pm 0.34$ \\
\hline $\mathbf{3}$ & PAN@ $0.14 \mathrm{~g} / \mathrm{cm}^{3}$ & $0.15 \mathrm{~g} / \mathrm{cm}^{3}$ & CPICA & $0.29 \mathrm{~g} / \mathrm{cm}^{3}$ & 1.1 & 430 & $4.8 \pm 0.53$ \\
\hline $\mathbf{4}$ & PAN@ $0.17 \mathrm{~g} / \mathrm{cm}^{3}$ & $0.12 \mathrm{~g} / \mathrm{cm}^{3}$ & PICA & $0.29 \mathrm{~g} / \mathrm{cm}^{3}$ & 0.7 & 560 & $5.6 \pm 0.12$ \\
\hline
\end{tabular}

Table 15. Summary of average bondline temperature measurements between Rayon TPS sections.

\begin{tabular}{|c|c|c|c|c|c|c|c|}
\hline $\begin{array}{c}\text { Sample } \\
\text { ID }\end{array}$ & Substrate Density & $\begin{array}{c}\text { Resin } \\
\text { Density }\end{array}$ & Infusion & $\begin{array}{c}\text { TPS } \\
\text { Density }\end{array}$ & $\begin{array}{c}\text { Resin to } \\
\text { Fiber \% }\end{array}$ & $\begin{array}{c}\text { Bondline } \\
{ }^{\mathbf{0}} \mathbf{C}\end{array}$ & $\begin{array}{c}\text { Recession } \\
\text { mm }\end{array}$ \\
\hline $\boldsymbol{1}$ & Rayon @ $0.09 \mathrm{~g} / \mathrm{cm}^{3}$ & $0.13 \mathrm{~g} / \mathrm{cm}^{3}$ & PICA & $0.22 \mathrm{~g} / \mathrm{cm}^{3}$ & 1.4 & 180 & $4.6 \pm 0.45$ \\
\hline $\mathbf{2}$ & Rayon $@ 0.09 \mathrm{~g} / \mathrm{cm}^{3}$ & $0.20 \mathrm{~g} / \mathrm{cm}^{3}$ & CPICA & $0.29 \mathrm{~g} / \mathrm{cm}^{3}$ & 2.2 & 190 & $4.1 \pm 0.20$ \\
\hline $\mathbf{3}$ & Rayon@ $0.09 \mathrm{~g} / \mathrm{cm}^{3}$ & $0.20 \mathrm{~g} / \mathrm{cm}^{3}$ & CPICA & $0.29 \mathrm{~g} / \mathrm{cm}^{3}$ & 2.2 & 160 & $3.9 \pm 0.36$ \\
\hline $\mathbf{4}$ & Rayon@ $0.14 \mathrm{~g} / \mathrm{cm}^{3}$ & $0.14 \mathrm{~g} / \mathrm{cm}^{3}$ & PICA & $0.28 \mathrm{~g} / \mathrm{cm}^{3}$ & 1.0 & 220 & $4.8 \pm 0.41$ \\
\hline
\end{tabular}

\begin{tabular}{|c|c|c|c|c|c|c|c|}
\hline $\begin{array}{c}\text { Sample } \\
\text { ID }\end{array}$ & Substrate Density & $\begin{array}{c}\text { Resin } \\
\text { Density }\end{array}$ & Infusion & $\begin{array}{c}\text { TPS } \\
\text { Density }\end{array}$ & $\begin{array}{c}\text { Resin to } \\
\text { Fiber \% }\end{array}$ & $\begin{array}{c}\text { Bondline } \\
{ }^{\mathbf{0}} \mathbf{C}\end{array}$ & $\begin{array}{c}\text { Recession } \\
\mathbf{m m}\end{array}$ \\
\hline $\boldsymbol{I}$ & Rayon @ $0.09 \mathrm{~g} / \mathrm{cm}^{3}$ & $0.13 \mathrm{~g} / \mathrm{cm}^{3}$ & PICA & $0.22 \mathrm{~g} / \mathrm{cm}^{3}$ & 1.4 & 200 & $6.2 \pm 0.44$ \\
\hline $\mathbf{2}$ & Rayon $@ 0.09 \mathrm{~g} / \mathrm{cm}^{3}$ & $0.20 \mathrm{~g} / \mathrm{cm}^{3}$ & CPICA & $0.29 \mathrm{~g} / \mathrm{cm}^{3}$ & 2.2 & 280 & $4.9 \pm 0.32$ \\
\hline $\mathbf{3}$ & Rayon $@ 0.09 \mathrm{~g} / \mathrm{cm}^{3}$ & $0.20 \mathrm{~g} / \mathrm{cm}^{3}$ & CPICA & $0.29 \mathrm{~g} / \mathrm{cm}^{3}$ & 2.2 & 220 & $5.3 \pm 0.55$ \\
\hline $\mathbf{4}$ & Rayon@ $0.14 \mathrm{~g} / \mathrm{cm}^{3}$ & $0.14 \mathrm{~g} / \mathrm{cm}^{3}$ & PICA & $0.28 \mathrm{~g} / \mathrm{cm}^{3}$ & 1.0 & 280 & $6.5 \pm 0.52$ \\
\hline
\end{tabular}




\section{Summary and Conclusion}

These tests were intended to explore several ambitious TPS development questions about carbon fiber reinforcement and pyrolyzing resin impregnation, which are highly relevant to the development of conformal ablator TPS materials. The tests explored the use of commercially available PAN based carbon fiber felt and rayon-based felt with varying percentage of phenolic resin loading to answer the following questions:

- Can different carbon fiber substrates be consistently and repeatably impregnated with phenolic resin?

- What is the tradeoff between using a mechanically stronger, higher conductivity substrate versus a mechanically weaker, lower conductivity fiber substrate?

- What is the best way to optimize a materials' thermal performance - by tailoring substrate density or by tailoring the percentage of pyrolyzing resin to reinforcing substrate?

It was shown that increasing the substrate density of rayon-based felts from 0.09 to $0.14 \mathrm{~g} / \mathrm{cm} 3$ did not necessarily reduce recession. The same was true for the PAN-based felts. Whereas increasing the resin to fiber ratio had a more noticeable effect in reducing both recession and peak bondline temperatures in both substrate systems

Changing the fiber substrate from rayon-based to PAN-based carbon fibers at similar densities with a similar increase in phenolic loading increased the bondline temperatures by $\sim 20 \mathrm{C}$ and $\sim 50 \mathrm{C}$ respectively, but decreased the recession by $1.7 \mathrm{~mm}$ (35\% of the PAN model's recession) or $1 \mathrm{~mm}(26 \%)$ for the low and high flux test conditions, respectively. The most closely matched specimens of the different substrates showed the expected key tradeoff between the two substrate materials' performance, in terms of recession and peak temperature, and offers the potential for selecting between materials, weighing recession and peak bondline temperature for similar TPS mass and loadings.

Increasing the resin density lowered the peak bondline temperatures for all materials. For the rayon-based materials, increasing the resin impregnation by $0.07 \mathrm{~g} / \mathrm{cm} 3$ yielded an $\sim 70 \mathrm{C}$ decrease in peak bondline temperature for the low heat flux test, and an $\sim 25 \mathrm{C}$ decrease for the high flux test. Comparing the temperature differences for each material at the two different test conditions, a larger difference is seen in peak bondline temperatures in the PAN materials at both test conditions, which may indicate some potential to perform better in higher flux levels. The highest resin-loaded sample of the three PAN models having the same substrate density of $0.14 \mathrm{~g} / \mathrm{cc}$ gave the lowest peak bondline temperatures, which may indicate the PAN models' bondline temperatures would be improved by the addition of relatively more resin, as observed in the rayon-based samples.

\section{Acknowledgments}

This work was sponsored by NASA's STMD Game Changing Development Program under the Entry Systems Modeling Project. The authors acknowledge Dinesh Prabhu (ERC, NASA Ames) for performing the CFD, Jose Chavez-Garcia (ERC, NASA Ames), Matt Switzer (NASA Ames), Joseph Mach (Sierra Lobo, NASA Ames), Jose Santos (Sierra Lobo, NASA Ames) for helping make the arcjet tests a great success.

\section{References}

${ }^{1}$ Beck, R. A. S., Driver, D. M., Wright, M. J., Hwang, H. H., Edquist, K. T., and Sepka, S. A., "Development of the Mars Science Laboratory Heatshield Thermal Protection System," Journal of Spacecraft and Rockets, Vol. 51, No. 4, 2014, pp. 1139-1150. doi:10.2514/1.A32635

2 “PICA Heat Shield," SpaceX, 4 April 2013, http://www.spacex.com/ news/2013/04/04/pica-heat-shield [retrieved 17 Nov. 2014]

${ }^{3}$ Fan, W., Gasch, M. Stackpoole, M. and Olson, M., "Conformal Ablators,” NASA TM -216382 (June 2012).

${ }^{4}$ Winovich, W., and Carlson, W., "The 60-MW Shuttle Interaction Heating Facility," Proceedings of the 25th International Instrumentation Symposium, Instrument Society of America, Pittsburgh, PA, 1979, pp. 59-75. 
${ }^{5}$ Empey, D. M., Skokova, K.A., Agrawal P., Swanson G., Prabhu, D.K., Peterson K. H., and Venkatapathy E., "Small Probe Reentry Investigation for TPS Engineering (SPRITE)", proceedings, 8th International Planetary Probe Workshop, Portsmouth, VA, 6-10 June 2011.

${ }^{6}$ Milos, F.S., Gasch, M.J., and Prabhu, D.K., "Conformal Phenolic Impregnated Carbon Ablator Arcjet Testing, Ablation, and Thermal Response," Journal of Spacecraft and Rockets, Vol. 52, No. 3, 2015, pp. 804-812. doi: 10.2514/1.A33216

7 Anon., "Standard Test Method for Measuring Heat-Transfer Rate Using a Thermal Capacitance (Slug) Calorimeter,” ASTM International STD E-457-08, Conshohocken, PA, 2008, doi:10.1520/E0457-08

${ }^{8}$ Wright, M. J., Candler, G. V., and Bose, D., "Data-Parallel Line Relaxation Method for the Navier-Stokes Equations," AIAA Journal, Vol. 36, No. 9, 1998, pp. 1603-1609. doi:10.2514/2.586 